Portland State University

PDXScholar

1972

\title{
W. S. U'Ren and the Fight for Government Reform and the Single Tax: 1908-1912
}

David Elvin Lindstrom

Portland State University

Follow this and additional works at: https://pdxscholar.library.pdx.edu/open_access_etds

Part of the Political History Commons, Public Economics Commons, and the Taxation Commons Let us know how access to this document benefits you.

\section{Recommended Citation}

Lindstrom, David Elvin, "W. S. U'Ren and the Fight for Government Reform and the Single Tax: 1908-1912" (1972). Dissertations and Theses. Paper 955.

https://doi.org/10.15760/etd.955

This Thesis is brought to you for free and open access. It has been accepted for inclusion in Dissertations and Theses by an authorized administrator of PDXScholar. Please contact us if we can make this document more accessible: pdxscholar@pdx.edu. 
AN ABSTRACT OF THE THESIS OF David Elvin Lindstrom for the Mastef of Science in Teaching in Social Science presented July 28, 1972.

Title: W. S. U'Ren and the Fight for Government Reform and the Single Tax: 1908-1912.

APPROVED BY MEMBERS OF THE THESIS COMMITTE:
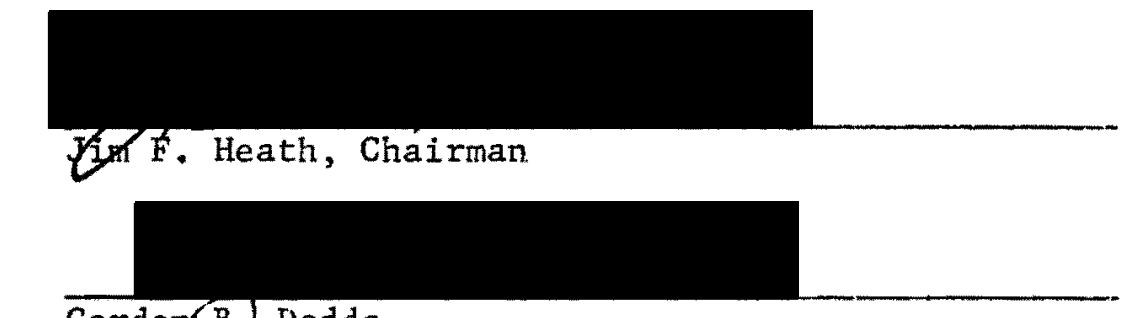

Gordon B. Dodds

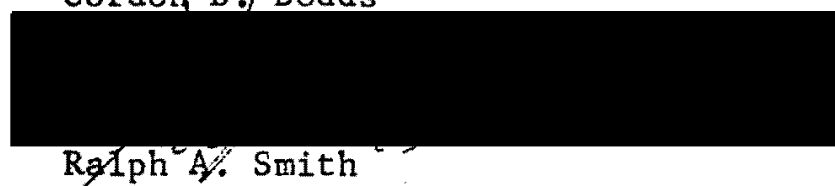

In the study of Oregon politics, the importance of developments in the early twentieth sentury have been largely overlooked by popuiar historians. As a result, many have lost the perspective of the sweeping reforms that reformers presented to Oregon's electorate. Another complicating factor is that voters dealing with the issues during the period had such disparaging attitudes towards some of the reforms, that no thought was given to preserving their memory for future generations. In addition, the personal papers of W. S. U'Ren, Oregon's leading reformer, are not available. This makes perspective even more difficult. Therefore, the research problem is basically attempting to place all the proposed reforms in perspective with one another and arriving at an idea of exactly what the reformers had in mind. 
The data used for the thesis, W. S. U'Ren and the Fight For Govermment Reform and the Single Tax: 1908-1912, was found in the personal papers of George Chamberlain, in newspapers, pamphlets, other theses, and official Oregon State publications. George Chamberlain's papers are found in the Oregon Historical Society, and provide valuable insight into the election year of 1908. The use of newspapers presented a problem, because many of them were antagonistic toward U'Ren's efforts. To balance the view, the Oregon City Courier was closely scrutinized because it was the most objective in dealing with reformer's proposa1s. Pamphlets were found in the Multnomah County Library, the Oregon Historical Society Library, and in the Oregon State Libraxy. They provided insights into the thinking of both reformers and counterreformers. Both the pamphlets and the newspapers, especially the Courier, aided in sensing the mood of people. The Oregon Grange yialded Information on the mood of farmers, an important part of the electorate, through records of state Grange sessions. The theses, found in the Oregon Historical Society, that contained interviews with people who worked with U'Ren were the most valuable. Records of the legislature and the tax commission, found in the Oregon State Library, were of Importance in gaining a view of the opposition to refonn.

W. S. U'Ren presented reforms which, if carried out, would have greatly altered Oregon government and eccnom;. In studying them, they appear to be workable, while placing more power in the hands of the people. Whether they actually would rork is impossible to know. The study does point to a sweeping program that the reformers had in mind that would have given every individual the opportunity to develop to 
the highest possible point, while eliminating crime and poverty. The inference is given that if Oregon adopted all the tax and governmental reforms that the reformers presented, the entire nation would follow the example. At that time, there was a widespread belief that as oregon went, so went the nation. Oregon's electorate only went part of the way with W. S. U'Ren and his supporters. The greatest factor in this is that money and corruption persuaded Oregon's farmers that the reforms would make them slaves to the government. This was simply not the objective of the reformers. In fact, the opposite was true. They wanted to free farmers from control by business and government. 
W. S. U'REN AND THE FIGHT FOR GOVERMMENT REFORM AND THE SINGLE TAX: 1908-1912

\author{
by \\ DAVID ELVIN LINDSTROM
}

A thesis submitted in partial fulfillment of the requirements for the degree of
MASTER OF SCIENCE IN TEACHING
in
SOCIAL SCIENCE

Portland State University

1972 
TO THE OFFICE OF GRADUATE STUDIES:

The members of the Committee approve the thesis of David Elvin Lindstrom presented July 28, 1972.
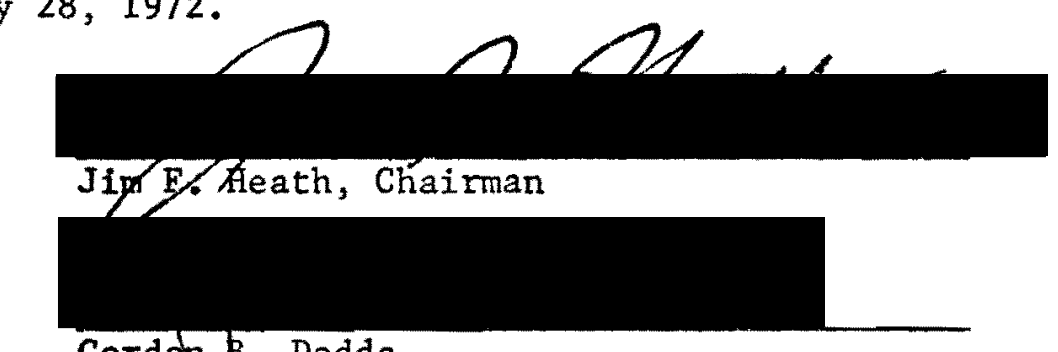

$$
\text { Gordon B. Dodds }
$$

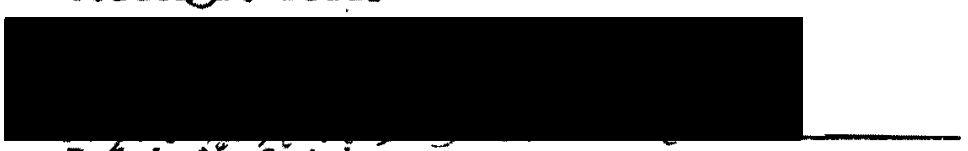

Balph $/$. Smith

\section{APPROVED:}

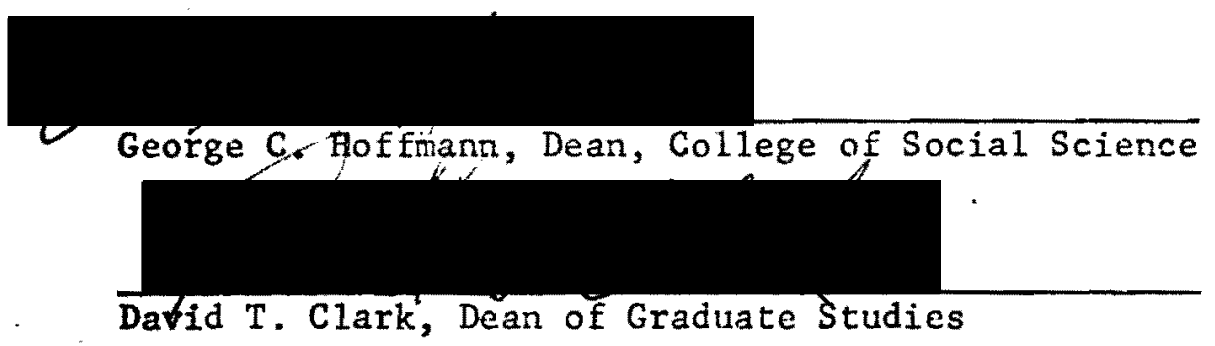

July 28, 1972 
TABLE OF CONTENTS

Page

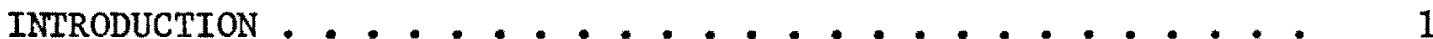

CHAPTER

I VICTORY FOR THE DIRECT ELECTION OF UNITED STATES SENATORS IN OREGON ................ 11

I. Statement No. 1 and Its Source........ 11

II. U'Ren Considers the Senate Race, While Political Interests Assess Their Positions . . 13

III. Govemor George Chamberlain Declares For the Senate Race ............ 24

IV. U'Ren Distrusts Chamberlain ........ 27

V. Chamberlain Wins Election: Special Interests Confronted In the Legislature . . 29

VI. Republicans Ridicule People's Rule . . . . 35

II U'REN'S PROPOSALS FOR EFFICIENT, REPRESENTATIVE GOVERNMENT: 1909 TO 1912 . . . . . . . . . 42

I. Voters Consider Basic Changes . . . . . 42

II. The 1910 Election Reveals Voter Concerns . . 47

III. The Second Campaign For Basic Reform . . . . 50

III REACTION BY THE SPECIAL INTERESTS TO SINGLE TAX AND GOVERIMENT REFORM ............. 64

I. Oregon Is Prepared For Single Tax: 1908 . . . 64

II. Special Interests Fight Back........ 71

IV TAX AUTONOMY FRIGHTENS THE LEGISLATURE . . . . . . 83

I. Voters Approve "Section 1a," ....... 83

II. The 1911 Legislature Prepares For the Single Tax Test . . . . . . . . . 93 
V THE 1912 SINGLE TAX DEBATED IN LETTERS AND

PAMPHLETS ..................... 102

I. The Issue .. . . . . . . . 102

II. The Oregon City Courier Promotes Single Tax

Discussion ............ 103

III. Pamphlets Express the 1912 Single Tax

Issue ............. 111

VI SURPRISES, ACCUSATIONS, AND DEBATES . . . . . . 124

I. A March Statement and the May Petition . . . 124

II. The 1912 Annual State Grange Meeting . . . . 128

III. The Shields and Brown Letters . . . . . . 130

IV. U'Ren Challenges the Opposition To Debate * 132

v. The Voters Say No ........... 140

BIBLIOGRAPHY . . . . . . . . . . . . . 145 
INTRODUCTION

At the turn of the century, Oregon, Iike many American states, was gripped by corruption as national political parties and big business worked together for their own ends. There are numerous instances of their disregard for democracy. Different organizations transported hired voters throughout Portland, who voted in the same election again and again and again. At times, repeaters traveled on foot, in towns and rural areas, to vote at several polling locations, without pay, for a friend or against an enemy. Other voters held up their ballots so the vote buyer was certain of getting his money's worth.

It was the practice to promise hard workers party nominations two to ten years in advance. Bills were passed and defeated by money and other forms of bribery. During legislative sessions, whisky was free and prostitutes were available. Such abuses were nost evident when the legislature was to elect a United States Senator. Legislators were persuaded to vote for one Senatorial candidate or another by outright cash bribes amounting to thousands, or by promising an appropriation for his district.

In the midst of Oregon's corruption appeared a "genius for organization and persuasion," William Sinon U'Ren. U'Ren had observed political corruption in Denver and became concerned. He traveled to San Francisco and became acquainted with Henry George's Progress and Poverty. U'Ren was profoundly convinced that George's system of land value tax was the solution he had been looking for to elininate 
corruption. He became a devout follower of Henry George, not only in the practical sense of an economic system, but also in the spiritual sense of George's background and philosophy.

Henry George was deeply influenced and motivated by the Hebrew experience and its result, Christianity. George viewed the Declaration of Independence and the American experience as extensions of the old Testament Jewish travels to the promised 1and. As in the Hebrew's story, George believed a benevolent intelligence controlled social laws, rather than blind, selfish forces. In his philosophy, the final plateau was life after death, the immortality of the soul. At the conclusion of Progress and Poverty, George made a strong appeal to his readers to accept immortality as the grand culmination of earthly existence. Many readers were attracted to George by this belief as much as by his economic philosophy.

Progress and Poverty is opinionated, idealistic, religious, economic, and transcendenta1. With this view, George saw the Republican Party becoming the enemy of reform and human freedom. While remaining a member of the party, he believed its policies were developing another class of slaves and denying the nation Biblical freedom that he believed President Abraham Lincoln established.

The Federal Govermment's practice of granting huge blocks of public land to private corporations, such as the railroads, alamed George. In this he saw destruction of freedom, and the eventual death of liberty. This drove him to rediscover Jacksonian principles, and to apply them to his times. Private interests acquired fortunes at public expense, while not even allowing Americans to share in the labor. 
Thousands of Chinese were imported, which lowered wages to ridiculous leve1s. George, taking the side of Jeffersonian agrarians, urgently opposed such practices.

George attempted to express the plight of West Coast wage earners and to consolidate their opinion into a strong force. He opposed President Ulysses Grant and free capitalism by dedicating himself to Jacksonian and Jeffersonian principles. He carefully studied the Jeffersonian theory of the "natural right" of man to the land. From this, George concluded that rent was a social product and did not belong to private interests. Taxing labor was not fair and discouraged improvement. Henry George perceived that wage earners became poorer as population and wealth increased. With population increases, land became valuable, and speculators placed the burden of taxes on the productive classes for the increased governmental needs. George determined to make land owners pay increased taxes. This would benefit wage earners by lowering their taxes and thus allowing them to improve their holdings without penalty. George believed that once his system, popularly known as single tax, was instituted, wage earners would also experience higher salaries.

George's land value tax viewed a11 land, developed and undeveloped, as equal. Therefore, the tax rate on all land was the same. Buildings and improvements were not taxed. In effect, the wealth would be more evenly distributed by forcing large land owners, or speculators, to develop their holdings. On a national leve1, the land value tax would eliminate all tariffs and create free trade. This would make large corporations more competitive and lower consumer prices. 
The single tax initiatives in Oregon were not pure land value tax measures, because it was feared the voters would not comprehend the 1ssue. In actual administration, collection was favored at the county level rather than the state level. This would prevent big business from designing the tax to favor them. In all the measures, the legislature was to aid the county in assessing value. The county would not only collect the tax, but was charged with giving the state its share. Ideally, the state would not directly collect any taxes. The "Christian Republic" which Henry George envisaged could only survive on progress that excluded poverty. He concluded that the right of men to have all their wants supplied and to have free use of resources without interfering with the rights of others was just and natura1. Henry George implied that he and Jefferson were right because their concepts were based on the teachings of Moses. George regarded Moses as having keen insights into the rights and ecoromic needs of men. The Egyptian ens lavement of the Hebrews was possible only through a small group owning the land. The Mosaic Code primarily protected humanity, not land. In George's view, the Code established a government built on the individual, with his need for land.

More important, the Mosaic Code prohibited, by the Sabbath, complete economic enslavement. George maintained the nation had adopted much of the Code, and to complete the work, its view of property and respect for working people had to be accepced. This sweeping philosophy has been called "Practical Idealism." The plan could work, in the view of such progressives as the famous educator John Dewey, if men would lend it their good will. Dewey implied that a special kind of faith was needed to give the plan life. 
Jacksonianism, Jeffersonianism, Judaism, Christianity, Moses, the Mosaic Code, and Henry George blended to produce U'Ren's motivation. To George's philosophy, U'Ren added his organizational ability, his practical politics, his persuasive ability, and his special kind of faith. With these credentials, U'Ren, who was studying law, quickly became the unquestioned leader of a small band of single tax enthusiasts which he found upon arrival in Oregon.

It must be said that U'Ren was an uncommon reformer during the progressive period. His counterparts were often engaged in muckraking only because of its popularity, while others were interested only in certain elements of reform. Still others were seeking personal profit. Many did not have a dogma and philosophy guiding their activities. U'Ren, however, had a philosophy and understood it. He was convinced his ideals were based on old and proven doctrine. His activities were carefully calculated. His quietness, his patience, his respect for corruptionists, all revealed a strong faith in a benevolent inte11igence guiding Oregon's reform movement.

Among popular reformers, U'Ren was peculiar because his ultimate goal was to enact the single tax. Many did not wish to devote themselves to a cause which was misunderstood and largely unpopular. U'Ren's faith permitted him to firmly believe that Oregon was the designated place for single tax to begin its national advance. Oregon had a small population, largely rura1, with 1ittle manufacturing. I'Ren believed he could eventually persuade farmers to accept the logic of single tax.

U'Ren realized the task was difficult and impossible in the hands of the Oregon State Legislature. In American towns, cities, and counties, single taxers urged their system cn voters. There were a few 
short lived successes as in Everett, Washington, and Houston, Texas. In both instances, insurgents persuaded the courts and tax commissions to declare the ballot measures unconstitutional. U'Ren was anxious to insure that the people's will in Oregon would not be circumvented. U'Ren echoed Henry George's plea for "power to the people." Thus, in the early $1890^{\prime}$ 's, U'Ren and his small band of single taxers began planning how to take power from special interests and corrupt political parties. The single tax was hated by the special interests and by the political parties they controlled. In order to defeat the interests, and thus give single tax a chance, U'Ren and his group determined the first step was to institute the initiative and referendurn. With these tools, the people could form their own legislation at the ballot box. In 1902, after several years of effort, U'Ren miraculously led the state to this achievement. This was the foundation of what became nationally known as the Oregon System.

To enhance the Oregon System, U'Ren proposed in 1904 the direct primary, which permitted the people to nominate candidates for the general election. An important part of the bill was a provision known as Statement No. 1, providing for direct election of United States Senators. This had been the legislator's task. After passage, y'Ren saw a need to submit another initiative in 1908 to clarify the meaning of Statement No. 1. The recall, another important part of the Oregon System, was also submitted and carried in 1908. These inroads in Oregon's legislative power were seen as making single tax a reality. Between the $1890^{\prime}$ 's and 1908 , when ground work was being formed for single tax, U'Ren did not publicly mention the single tax issue. During this period, his supporters constantly pushed for an open fight 
over single tax. T'Ren had to use all his'skill and persuasion to hold them off, arguing that the voters were not ready, and that a premature battle would eliminate all possibilities of gaining single tax. Before 1908, there were several times when a break between U'Ren and his followers seemed probable. However, U'Ren always maintained his position.

A1though not fully documented, it is highly probable that U'Ren and his fellow single taxers believed the elections of 1908, 1910, and 1912 were critical, and that they would determine success or failure of the final steps in assuring power for the people and the institution of single tax. If one believes that U'Ren was a devoted disciple of Henry George, then Oregon was not the only thing on U'Ren's mind. During these critical elections, the welfare of the entire nation was being considered, and hope for the Christian Republic was nurtured.

The five year period between 1908 and 1912 represents the height of U'Ren's influence and, ironically, culminated in the end of his far reaching leadership. The object of this study is to review the period, and to define the factors that brought a halt to Oregon's reform movement. It will become obvious that Oregon voters were willing to go only so far with U'Ren. It is less clear why they drew a line and refused to accept his full, sweeping program.

Some theses and dissertations have been written about W. S. U'Ren. Several theses are William Simon U'Ren: In An Age of Protest (1956), by Robert C. Woodward, and W. S. U'Ren and the Oregon System (1950), by Scott W. Reed. A recent dissertation is William Simon U'Ren: A Study of Persistence In Political Reform (1967), ¿y Esther G. Weinsteir. 
These works cover U'Ren's life span, and largely report the facts without placing them in perspective. They fail to show the relationship between the different reforms that were proposed. The era is filled with much detail, and often it is difficult to understand anything except the names of different leagues and the sequence of events. Writers are impressed with his patience and leadership, but they fail to explain the broader aspects of his program which explain his approach. The elections of 1908, 1910, and 1912 explain much about why U'Ren was so urgent about the reform policies.

In 1908, Oregon voters "officially" heard of single tax for the first time. They were invited to study the proposal in a low key campaign. In 1910, voters were asked to decide if it was just for individual counties to have the option to choose their own tax system, including single tax. Then, in 1912, Oregonians were asked to make a firm commitment in behalf of single tax.

Between 1908 and 1912, U'Ren and his supporters tried to insure that Oregon would forever be ruled by the people. U'Ren was not sure how single tax would be received. It was important to press as much legislation to break the grip of corruption as possible. It was necessary to guarantee the direct election of United States Senators. Initiative and referendum powers needed expanding. U'Ren was aware that because of his efforts up to 1908 , the Oregon Constitution was a patchwork affair that needed to be improved. Thus, he proposed to voters a series of amendments that would pull the Constitution together, make significant changes in government from the state level down to the cities, provide a solid framework in which single tax could work, and 
insure good government so the initiative and referendum powers would only serve as emergency acts.

To fight the forces who waged a strong campaign to take power from the people between 1908 and 1912, U'Ren used his People's Power League to good effect. This body was reorganized for each election, but always contained a small core of devout single taxers. Presidency of the League was an honorary position and meant little by way of influence. To be a League member, a contribution was expected, and U'Ren, who served as secretary, always attempted to gather five hundred subscribers.

The complexities of this period are difficult to describe. U'Ren and his League, which took several forms, such as the Oregon Single Tax League, were urging single tax while pressing for governmental reform and complete protection of the people's rights. The reformers found themselves fighting money, corporations, and corrupt political parties just to keep what power the people did gain. This combination, plus leading Portland families and professional political party machine workers, is often referred to as the "special interests." National organizations also aided the enemies of the people's power and can be considered a part of the special interests.

The reader may question why the reformers urged single tax and governmental reform in the face of such danger. One answer is timing. Ten or twelve years of intensely promoting reform was about all the people had patience for. U'Ren sensed this and doubtlessly regretted all the generated confusion and powerful opposition. He knew this would 
detract from his reform efforts. There are implications that opposition organizations placed senseless initiative measures on the ballots just to confuse voters and make them disgusted to think that U'Ren had the nerve to burden them with such complexities.

This study will attempt to clarify the critical issues and movements during this complex period. This task would be much easier if the U'Ren papers were available for scholars to use. For U'Ren the years between 1908 and 1912 were ones of a frustrating near-miss in achieving government reforms and securing adoption of his cherished single tax. His hopes were defeated because he and his supporters aroused the anger of the special interests. Try as they might, the reformer's logical arguments could not overcome the fears aroused in Oregon's electorate by the numerous hired agents of the special interests. And in the end, the power of the interests simply proved to be too strong. 
CHAPTER I

\section{VICTORY FOR THE DIRECT ELECTION OF UNITED STATES SENATORS IN OREGON}

I. STATEMENT No. 1 AND ITS SOURCE

A key polftical issue in 1908 was the continued validity of Statement No. 1, a pledge candidates for the state legislature were asked to take in which they promised to vote in the legislature for the people's choice for the United States Senate. Big business and the Republican Party oppose Statement No. 1, because it effectively controlled their power at the state and national level. They argued that no legislator had the option to give away his voting rights to the people. As will be shown, the national press and the National Committee of the Republican Party had an unusual interest in Statement No. 1.

U'Ren gave Oregon's junior Senator, Jonathan Bourne, credit for being one of the first to consider Statement No. 1. However, U'Ren greatly figured in gaining Statement No. I's adoption for Oregon.1 U'Ren sald that while Senator Bourne was the first to mention it, many contributed to the 1aw's details. The argument in the 1904 Voters Pamphlet favoring the bill was mostly the Senator's work. Bourne paid to Initiate the bill and may have originally obtained the idea from Alabama when the state's Democratic Committee asked that Bryan be placed on the primary ticket. 2 The Oregon voters accepted Statement No. I in 1904, 
because they were disgusted with their legislators accepting bribes from special interests to vote for a Senatorial candidate.

In 1906, Jonathan Bourne became the first candidate elected to the Senate by Statement No. 1. He sent addressed personal letters to all registered voters. The old leaders and corporations thought the whole Idea a joke. Mail had never been used before to reach the people. $U$ 'Ren and his associates traveled the state getting men who supported Statement No. 1 to run for the legislature. The local Republican machine candidate usually refused, but U'Ren saw to it that a No. 1 candidate was found. Many times he sat all night with farmers, persuading, begging, and imploring them to stand on the principle as candidates. U'Ren succeeded. In all districts men stood for No. 1, a new phenomenon in Oregon politics. The effort was successful, because the 1907 legislature elected Bourne as United States Senator.

In 1908, there was a great threat of electing a Senator opposed to Statement No, 1 and to rest of the Oregon System. The term of Oregon's senior Senator, H. J. Fulton, expired in 1908, He was a corporation Senator and was implicated in Federal land frauds. There was great public interest in the Senator's land dealings, and one of the Federal prosecutors, F. J. Henry, addressed over 1,400 people in Portland on the subject. 3 U'Ren was alarmed because of rumors that the Republican Machine was going to support Fulton in spite of the fraud implications and try to overthrow Statement No. 1. 
II. U'REN CONSIDERS THE SENATE RACE, WHILE POLITICAL TNTERESTS ASSESS THEIR POSITIONS

In January 1908, U'Ren seriously considered running for the United States Senate. The general public was not aware of the fight brewing to eliminate No. 1. But U'Ren was aware, and later said this threat was the only reason he considered running. However, U'Ren had been remotely considering the race as a Republican for several years. Ile told the Oregon City Courier that the race depended on gaining favor with the newspapers. ${ }^{4}$ As expected, Senator Bourne assured U'Ren of his support. U'Ren placed much faith in the impact on voters of an article in the American Magazine by Lincoln Steffens. The article argued that U'Ren was the father of the initiative and referendum. Bourne was expected to aid U'Ren by gaining a statement of support for the candidate from President Theodore Rooseve1t.

Between January and February, U'Ren vacilated in making a decision to run. This may have been to throw the opponents of statement No. 1 off guard. At the end of January, U'Ren said he was not a candidate for the Senate. In reviewing the decision, several publications asserted that U'Ren had his own private legislature to take care of, referring to the supporters helping him with initiative measures.

A reporter asked U'Ren if he would like to be Senator. He replied:

No, though I would like very much to have the office, because of the opportunity it offers for work in extending the initiative and referendum to national law making. It is impossible to realize the dream of equal rights in our Declaration of Independence until special privilege is abolished; particularly special privilege in land . . money ... transportation ... taxation by the tariff, and other methods.

The politicians cannot abolish special privileges, but when the people of the United States have power to make laws and amend the Constitution without consent of Congress or the Supreme Court, 
and at the same time neither Congress nor the Supreme Court can make or break laws in opposition to the people's will, they will destroy more special privilege in ten years than all the political parties, politicians and office seekers have been able to cut off since the Mayflower landed at Plymouth Rock.

But for this campaign it seems very clear to me and to my friends and counsellors that my duty is to work for the nomination and election to the Legislature of candidates who pledge themselves without reserve to obey instructions the people give at the June election; also, I want to advocate the measures proposed by the People's Power League.

The reporter asked U'Ren, "Are you going to take an active part in the coming campaign?" U'Ren declared:

Yes, as active as I am able to. I want to help to show the voters of Oregon that they may safely trust themselves with power. American history proves this, and proves just as clearly that they cannot safely trust any candidate who is willing to put his own judgement and power, or the judgement and power of his political party, above the will of the people on any question from the election of a precinct constable to the choice of a United States Senator.

My faith is strong that the Republicans of Oregon will nominate candidates who are willing to trust the people and to obey their instructions. With such men on our ticket, the people will trust the Republicans this year as they have for many years past.

At this point in the interview, U'Ren was asked if he would support Henry Cake as the Republican candidate for the April primaries. U'Ren replied:

I do not expect to make any special effort for the nomination of any candidate for the United States Senate. Our work will be principally for preserving and increasing the power of the people. The all important question is not who shall be Senator, but who shall select the Senator, the people or the politicians. 5

This interview is remarkable because it is one of the few statements by U'Ren, in print, summarizing his far reaching national goals and beliefs. While his desires for the Republican party did not prove true, the designs on candidates for the legislature did. While not mentioning single tax by name, he implied it was needed to break up special 
privilege and to make the Declaration of Independence effective.

Desplte his claim of being a candidate of the people, U'Ren was unable to woo the support of the Grange, a powerful farm organization. By 1908, the Grange, as never before, was becoming the most influential farmer's group. Oregon farmers increasingly relied on this organization for giving united expressions concerning their sentiments on public questions. In Grange halls all over Oregon, discussions raged over proposed legislation, both state and national. The result was a stamp of the farmer's sanction or disapproval. 6 Grange decisions took the position of making or breaking measures and politicians.

In early February, Mrs. Clara Waldo, Grand Lecturer of the State Grange, delivered a speech at the Salem Grange. She told the farmers to carefully study the bills and proposed amendments. She advised them to vote "no" if they did not understand them. "Better wait for the legislature than vote without understanding the Bill." Mrs. Waldo hit U'Ren for promoting initiative measures. She felt this weapon was overused and asked farmers to disapprove its frequent appearance. She failed to show that in most elections, of al1 the measures, U'Ren's amounted to less than half. She said U'Ren was not the father of the initiative and referendum, but maybe a step-father. Seth Llewelling, an early Oregon reformer and friend of U'Ren, was given the credit. Ironically, both men served together on a Grange committee discussing the matter. As a result of the Salem speech, several letters passed between Governor George Chamberlain and Mrs. Waldo. In a February 10, 1908, letter, the Governor agreed with her concerning the many bills coming up for approval in June. But he stressed the people's right to rule must be protected. He said: 
I feared from the very brief report of your address recently delivered that your language might be construed as criticizing indirectly the direct primary system as well as the method provided for electing a Senator. Do you not think that the Granges of the state ought to take this question up and advocate the signing of Statement No. 1?7

Because she had great influence, Governor Chamberlain asked Mrs. Waldo to have the issue discussed by the Granges. The Grange's position was enhanced by the Governor's concern, and the Grange's influence was one reason why U'Ren was a member. His membership was unusual, because U'Ren was an Oregon City lawyer, and not a farmer.

Mrs. Waldo quickly answered the Governor's letter saying he was misinformed about her attitude on direct legislation and Statement No. 1. She said:

I oppose anything that Mr. U'Ren may do to meddle with the Direct Legislative Law, the Initiative, because I believe him to be an unwise leader, but Statement No. 1 is likely to be strong1y supported by all Patrons of Husbandry. The Granges over the state are preparing to pass resolutions favoring this, and I shall inspire them to do all that we can to upholding both Statement No. 1 and full use of the Initiative and Referendum.

She concluded by assuring the Governor he had nothing to fear from the Grange, as they would stand behind him as always. Her feelings about U'Ren were not explained, and never were, but they continually prevaded the Grange. There was the strong possibility of jealous feelings between the Grange and U'Ren. On the otherhand, her expression of support for Governor Chamberlain helped him to make the decision to run for the United States Senate in the Democratic primaries.

The Governor answered her second letter expressing fear that popular legislation in Oregon was at its most critical stage. He said there was a determined and "organized effort being made by machine 
politicians of the old school to nullify the effect of all this legis1ation."8 The eyes, he declared, of the whole country were on Oregon. As a result, Chamberlain said he was receiving many invitations to speak in the East on threats against the initiative and referendum. However, he told Mrs. Waldo he could not accept them because of his possible entrance in the Senate race. This was a careful probe of whether or not the Grange would support his candidacy.

The Governor believed Statement No. 1 was the important issue, and he believed the Grangers and labor would favor it. 9 The Grangers and labor had cooperated before, and he was counting on their united effort to apply pressure on the legislature to honor the people's will and force Republicans to support Statement No. 1. Chamberlain urged that pressure be applied to elect Democrats favorable to No. 1 to the legislature. What kind of pressure was not explained. However, there was reason to believe that not all Democrats supported Statement No. 1 . Part of the reluctance by Democrats was explained by Berry F. Allan of Astoria, Oregon. He reported to the Governor that as a Democratic member of the 1901 legislature, he was offered $\$ 2,500$ to vote for Republican J. H. Mitchell as Senator. The offer came from Senator Fulton. The deal was set that if Fulton, also a Republican, helped Mitche11 in 1901, Mitche11 would help Fulton in 1903 with the Senatorial race. During 1901, Allan was besieged with letters suggesting he vote for Mitche11. Then, in 1903, Mitche11 did successfully he1p Fulton. In 1901, Allan said Fu1ton was looking beyond 1903 to 1908, when he realized Democratic help would be needed to help him win. Between 1901 and 1908, some Democrats were purchased and pledged to help Fulton in 
1908. This state of affairs was one reason why the Democrats were so unorganized for the 1908 campaign. Republicans suspected Chamberlain would declare for the Senate. They were aware Statement No. 1 was popular with the people, and could elect Chamberlain. Thus, Repub1icans planned to vote for Chamberlain in June and gain a majority of Statement No. 1 Republican legislators. Then, in the legislative election, Republican members would find some excuse for not supporting the Governor, and elect Fulton. Although Chamberlain had some idea of the scheme, he was not aware until later that Fulton was the Republican machine's choice for the Senate. Publicly, Republicans were supporting Henry Cake, a mild supporter of Statement No. 1.

Sam White, a lawyer in Baker City, was a good friend and advisor of Governor Chamberlain. The Governor laid out his fear to White that if the people did elect a Democrat for the Senate, the Republican legislature would elect their own candidate. By expressing this fear, Chamberlain was actually testing the winds to help him with his final decision.

Lacking organization, the Democrats were also without money. They could only run on principle. Democratic leadership was depending on Oregon voters tiring of the illegal Republican methods. 10 Not all top Democrats were Statement No. 1 men either, but as the popular mood was sampled, they quickly adopted the Statement as the key to votes. Sam White was one of the first to advance this view to the Governor. 11 Ihis reasoning was discovered by U'Ren and later he made it public. However, the Oregon voter was not alert enough to pick it up. As Republican leaders assessed 1908, they became fearful of their ability to elect anti-Statement No. 1 men to the legislature. Their 
fear was evidenced in the February 13, 1908, Oregonian. An article appeared denouncing the Corrupt Practices Act which the People's Power League was supporting because of criticism over the expensive campaign Senator Bourne ran in 1906. The Act linited campaign expenses to twenty-five percent of the office salary. This would cramp the usual Republican style, but they complained the Act suppressed freedoms of speech and press. It was declared a hardship on honest men running for office and an aid to unscrupulous men.

The statement was characteristic of the Oregonian. In fact, the Act was not an aid to unscrupulous men. Evidence suggests that the Oregonian was not only cooperating with the Republicans and big business but was among the leaders of corruption. The echo of smaller papers revealed the Oregonian's influence on them. The Oregonian also complained about the voter's pamphlet which described each of the candidate's beliefs. This, of course, was a hinderance to Republicans who did not want to run in support of Statement No. 1. Shortly, many Oregon papers denounced the pamphlet as unnecessary expense for taxpayers.

The week of February 24, caught Oregon by surprise. W. S. U'Ren declared for the United States Senate on the Republican primary ticket. The shock sent worried campaign managers into huddles. U'Ren's statement clearly detailed his position and added understanding to the campaign issues:

I have had this ambition for many years, but it is my hope that it would be the rule of Oregon for the office to seek the man before I became a candidate. And I hoped that I might then be one of those whose record for useful service to the state would cause the office to seek me. I abandon the latter part of the dream now because no candidate in Oregon 
for that office is fighting aggressively for the right and power of the people, both in the state and the nation to make laws and select and control their officers as the people of Oregon now do; and also because no candidate for that office in Oregon is actively supporting President Roosevelt in his rebellion against government of the United States by Standard $0 i 1$ and its allies.

Mr. Cake is of the same nature as the Great Compromiser. For nearly four weeks he has been absolutely silent and all the time under a most bitter vigorous and persistent attack on the right of the people to pledge candidates for the legislature by Statement No. 1.

I charge also that Senator Fulton is a true and loyal supporter of Standard $0 i l$ and its allies. I have never heard that Senator of his friends to have a good word for President Roosevelt, or for any other of the 1ittle group of Roosevelt rebel senators against government of the United States by Standard $0 i 1$ and its allies. 12

There followed in the statement, a lengthy 1ist of policies that U'Ren would support. No other candidate provided such a complete statement of beliefs for voters to examine. U'Ren's comments revealed an unusual understanding of trends, events, and government. U'Ren had said he needed support from the papers to win. Their treatment of his notable confession showed he did not have that support.

Rather than give U'Ren credit for his statement, papers brought a series of charges showing him to be a suspicious character. The charges actua1ly hurt Oregon, because U'Ren was the only candidate supporting policies that would enhance the state as a prosperous seaport and trade center. The Oregonian contended that U'Ren had gained powers over Seth Llewelling through hypnotism and as a medium represented the spirit of Llewelling's dead son. This was said to have happened when U'Ren first came to Oregon and lived with the Llewelling family. Later, U'Ren was taken into the Llewelling"s nursery business, and $\mathrm{Mr}$. Ilewelling's widow told the Oregonian that $U^{\prime}$ Ren mismanaged the business to the point she could not pay the debts. While living in the 
Llewelling home, U'Ren conducted his campaign for the initiative and referendum. The widow insisted that U'Ren did little to pass those measures and that her husband deserved the credit.

U'Ren replied that when he was made a partner, the family was already in deot five or six thousand dollars, and when the panic of 1893 hit, he attempted to break the three year contract they had formed, but without success. He did not claim credit for the initiative and referendum, saying all the credit was given to him by others. In addition, he was accused of cheating an old widow 13 and was accused by the we11 known populist, J. D. Stevens, of being involved in a man's death during the 1897 legislature. ${ }^{14}$. The effect of these charges is difficult to assess, but judging by letters and comments in papers, few voters, with the exception of some Grangers, took them seriously.

Governor Chamberlain communicated with Sam White concerning U'Ren's entrance in the race, expressing his belief that Senator Fulton would be nominated during the Republican primaries. 15 Chamberlain was still debating over entering the Senatorial race. White assured him U'Ren could be defeated and that the legislature would hold to Statement No. 1 , even if the primary winner was a Democrat. 16 White's reassuring conments encouraged Chamberlain to write a series of letters during March to Democratic friends urging them to run for the legislature on No. 1. To James F. Mahan of Harvey County. he wrote, "You must run on No. 1. You must sacrifice personal interests and inclinations and defeat Parish." Parish was the Republican candidate, while "inclinations" may indicate Mahan had doubts about Statement No. 1. Just as Chamberlain's hopes were rising, the Oregon City Enterprise carried ar editorial on February 28 in support of Senator Fulton 
and in opposition to Statement No. 1. The rationale was that a Republican Legislature might have to vote for a Democratic Senator. However, the Clackamas County Republicans, at their convention, got around this possibility by not voting on Statement No. 1 . The issue would have split the convention. Thus, a motion was made to remove the resolution, and the party promptly adopted the motion.

The Multnomah County Republican Convention was not so diplomatic. The vote was against No. 1. The intent was to insure that all other county conventions would follow the lead. Then the Convention denounced U'Ren for his stand on No. 1. The reformer promptly offered to meet anyone in public and debate the issue. The South Portland Republican Club agreed to sponsor the event and set March 5 as the date. Beyond that, U'Ren could not arrange any other significant debates as many were afraid of his speaking abilities.

The denunciation of U'Ren threatened to split the Republican Party. U'Ren's fondest hope was that his party would take the lead for No. 1. His disappointment was great, but U'Ren set about patching things up. He wrote a lengthy letter to Henry Cake imploring him to resign from the race along with himself, and together they would select a new candidate who supported No. 1.17 This would take the controversial U'Ren out of the campaign and replace a weak No. 1 man, Cake, with a strong candidate. Party leaders were trying to hide the split from the public, and U'Ren, as much as he disagreed with them, was helping. Cake, however, did not feel as magnanimous as U'Ren and turned him down. U'Ren was getting desperate, and on Friday, March 13, in the interest of No. 1, announced his withdrawal from the Senate race. He declared 
support for Fenry Cake, while denouncing, on the basis of working towards a modified Republicanism, the Republican magnet Harvey Scott, owner of the Oregonian, and several other individuals.

Upon hearing of the Republican split, George H. Shebley, President of the National Federation for the People's Rule, located in Washington D. C., communicated with Governor Chamberlain expressing fear that Oregon was about to lose the people's rule. He condemned the Oregonian for making statements without proof. Shebley said he was making speeches in the East and publicly denouncing the Oregonian. He held up the people's accomplishments and asked why the Oregonian did not do 1ikewise. Alex Setton of Astoria warned Chamberlain that if he ran for the Senate "al1 labor will be turned against you."18 Setton was saying that the machine would use imported money to buy labor. The Republican Party's industrial supporters and the Oregonian's questionable activIties suggested there would be unlimited money available. U'Ren understood this possibility and attributed it to his withdrawal from the Senate race. Several papers lauded U'Ren for his willingness to make this decision. "Mr. U'Ren's withdrawal is a distinct advantage. . because it reduces the number of statement No. 1 candidates. . In retiring, Mr. U'Ren puts principle above all other considerations, if he has enemies, they must admire the act."19 Papers declared he understood the voters' minds by putting principle before ambition. His withdrawal and entrance reasons were the same. Cake was not so understanding, because he believed his popularity would be sufficient even if the Oregonian disliked him.

U'Ren understood that No. 1 was opposed by Scott and other wealthy men who would support Fulton and elect uncommitted No. 1 men to 
the legislature. If the Statement No. 1 legislators provided a narrow margin, this "gang" would go to Salem to insure election of their Senatorial candidate. Scott, assuming the Governor would run, was delighted that each party had a No. 1 man. He belleved this would create confusion during the primaries with neither one being elected. Reformers feared Scott because he began to hate not only Statement No. 1 but showed a desire to crush the whole inttiative and referendum movement. This was interesting because he was an early supporter of the movement. However, he had intended to use the power to establish himself as the boss of oregon. When this did not materialize, he opposed a11 reform measures. 20

\section{GOVERNOR GEORGE CHAMBERIAIN DECLARES FOR THE SENATE RACE}

Governor Chamberlain felt the urgency to defend the initiative and referendum. He traveled the state making speeches in their defense, while taking a private poll on his chances for the Senate. His effectiveness was felt nationwide, as he was asked to become the VicePresident of the National Federation for People's Rule. In this post, it was argued, he could become more effective in the defense of the initiative and referendum. In this context, Chamberlain received a letter from E. E. Wilson, an attorney in Salem, expressing a state wide problem of finding people to run for Statement No. 1. This was even more peculiar because the issue was popular with the people. 21 The situation encouraged the Governor to write another series of letters to individuals urging them to run in behalf of No. 1. A typical one was to Oscar Hayer of Dallas, Oregon, "If you don't feel like making the 
sacrifice, you ought to get in a good man... Don't let it go by default."22 After urging Republican and Democratic friends, Chamberlain announced his candidacy on March 14 for the United States Senate on the Democratic ticket. 23

Chamberlain's advisors found that Fulton's people regarded Cake's organization of using foul means to get official Republican support for the primaries. 24 Few were aware of the secret deal between Fulton and the Republican machine to support Cake with hopes of overturning Statement No. 1 in the legislature. Fulton's supporters switached to Chamberlain, since Cake also advocated No. 1. This was what top Republicans wanted. The Republican County Central Committee in Astoria switched from Fulton to Chamberlain, 25 and many other Republican Committees followed. To actually vote for Chamberlain in the primaries, voters would have to change their party registration. There was not any evidence of this, but it did encourage Democrats pledged to support Fulton to alter their plans and vote for Chamberlain.

On Friday, April 17, primaries for Senatorial candidates took place. Chamberlain won on the Democratic ticket, and Cake won over Fulton for the Republicans. Also, a predominance of Republican Statement No. 1 men were elected to the state legislature. Then, on April 28, in St. Johns, Chamberlain opened the second phase of the campaign for Senator. He was jubilant after his speech. He had a good start, and Henry Cake was still hedging on No. 1.26 The Catholic church had informed Chamberlain of their support, which was of a quiet nature. The extent and importance of this support is difficult to determine. Senator Fulton was not visibly shaken by his dwindling support. The Oregon City Courier sent a correspondent to Washington, D. C., to 
gather national information on Fulton. He reported that Eastern interest in Oregon was more than usual. Statement No. 1 was the reason. Bourne had been elected under it, and the establishment was fearful of it. Statement No. I could "shelve" Senators who for years were owned by trusts with "complete mastery" over state legislatures. If No. 1 held, the steel trust, sugar trust, and ship building trust would not be able to "own a Senator or two." Common talk in Washington was that capitalistic organizations were ready to contribute "a few millions to nip in the bud any tendency to get away from old election methods." Washington was waiting to see if money could return Fulton. Fulton tried to appear as anti-big business, but could not fool many. The correspondent said:

The President is interested, his cabinet is interest, political circles are interested. If oregon comes out good and strong for No. 1, there will be, in a very short time, other states electing Senators in the same manner. If Statement No. 1 fails, the popular election of United States Senators will be put back many years. No wonder the Nation is looking on. 27

U'Ren now felt better about stepping out of the Senatorial race to fight for direct election of Senators. Outside of Taxation, this was the greatest area of direct industrial control over the country. Contrary to these beliefs, the Republican delegates from Oregon at the National Convention in Chicago voted against a plank supporting direct election of Senators. Charges were made that only those in opposition to No. 1 were allowed to select delegates during the May Republican state convention in Portland.

As Lincoln Steffens reviewed the attack in Oregon on No. 1, he wrote to Governor Chamberlain expressing fear about his candidacy, He believed Chamberlain went back on a statement he made to Steffens 
during May, 1907. The Governor then had said he would not run, but would fight for Statement No. 1. Friends were asking Steffens for copies of the 1907 conversation, but he was refusing until Chamberlain could answer. 28

Chamberlain replied, justifying his candidacy as coming only after urging friends to run for the legislature on Statement No. 1 . The Governor asserted he had assurances from Fulton not to interfere in the legislature's work. He revealed that Cake, in his opinion, vas part of the Republican Machine's conspiracy against No. 1 from the beginning, but was tricked by the Machine to think he had their support when they really favored Fulton. Chamberlain added that Cake was in the same position as Fulton of refusing to interfere in the legislature's work. These assurances satisfied Steffens that the Governor was not betraying anyone's trust. 29

As with Mrs. Waldo, Chamberlain gained Steffen's favor in part by revealing some inside information. To say that Cake and Fulton would not interfere in the legislative election did not exclude Republican leaders from interfering, and Chamberlain knew it. He had no choice but to rely on the legislature, since his efforts to encourage support for No. 1 were now useless. The Governor was also aware that U'Ren would make an effective case for No. 1 regardless of who the candidate was.

\section{U'REN DISTRUSTS CHAMBERLAIN}

U'Ren was not as trusting of Chamberlain as Steffens. On May 24 , U'Ren wrote to the Governor suggesting he quit the race because there 
was not a safe margin of No. 1 men in the legislature. The Governor was told he would have more influence for No. I if he was not a candidate. He should work for election of No. 1 legislators, U'Ren wrote, in the June general election, rather than "gratifying your selfish ambition to be Senator."

U'Ren charged that in 1902, the Governor disregarded refomm. In 1906, the letter continued, during the Statement No. 1 campaign for Bourne, the Governor made little effort to help. During that same year, an anti-No. 1 man, Milton Miller, a good friend of Chamberlain, won against a Statement No. 1 Democrat. While running for reelection in 1906, Governor Chamberlain made no mention of Statement No. 1 in his speeches. U'Ren continued:

Are you not something of a pharisee, a 'Holier than thou' when you accuse Mr. Cake of being untrue to the principle because he does not seek to elect about thirty-five Democrats and five independent Statement No. 1 candidates for the legislature, instead of forty Republicans who were nominated by the Republican voters of their district, notwithstanding their refusal to sign Statement No. 1 ?

As between $\mathrm{Mr}$. Cake and yourself, he has done more for Statement No. 1 than you. He is risking defeat now from Republicans who will vote for you because they hope to give you the popular vote now, and defeat you in January in the legislature. They believe they can prevent the election of a safe Statement No. 1 majority, 30

If U'Ren was aware of Chamberlain's suspicions that Cake was a machine. man from the start, he did not acknowledge it. U'Ren may have believed Chamberlain was using No. 1, while Cake was just a tool, and not intelligent enough to know it.

Upon receiving U'Ren's letter, Chamberlain summoned W. H. Jensen of the Oregon Agriculture College in Corvallis. During the night, Jensen did stenographic work in preparing a reply to U'Ren. Obviously, 
to give the reply such special treatment, Chamberlain feared U'Ren's charges. What Chamberlain said is unknown, but it produced a quick response from U'Ren. Within five days from the time U'Ren sent his letter, he had received Chamberlain's reply and had made his appeal to the Governor's public record. His public statement was similar to the private letter. The effects may have caused voters to wonder why U'Ren so strenuously defended Cake, because it was also public record that he was a weak No. 1 man. Governor Chamberlain was popular, and U'Ren's abusive letter gained sympathy for him. U'Ren's action was out of character, pointing to a crafty move by Chamberlain. If U'Ren was tricked, it was a rare occurance.

\section{CHAMBERLAIN WINS ELECTION: SPECIAL INTERESTS CONERONTED IN THE LEGISLATURE}

U'Ren's public "Chamberlain statement" declared he would fight for anyone, Democrat or Republican, who supported Statement No. 1.31 In spite of his feeling that voting for Chamberlain would defeat No. 1, In June the voters elected the Governor to the Senate post. Yet, there was one more confrontation, the January session of the Oregon State Legislature. Harvy Scott of the Oregonian ridiculed the "Holy statement." He said Oregon had been overridden by all the "hobbyhorse riders" in the country. "It was the fool of the family of States." 32 The Repub1ican machine openly demanded that legislators violate Statement No. 1 and asked Washington D. C. for help. However, President Roosevelt stood behind Chamberlain.

U'Ren confided to A. W. Cauthorn of the Portland Journal that his activity in the campaign was caused by fear over No. 1. He was convinced 
there would be a hold-up legislature because Chamberlain had won. U'Ren reiterated to Cauthorn his pledge to work harder than any man in Oregon to insure Chamberlain's election in the legislature. 33 There was good reason to work hard if the dire prediction of Sam White, Chamberlain's close friend, was true. He wrote to Chamberlain:

The opposition will have a larger corruption fund than at any other time in history. The fund will purchase No. 1 men to vote against you. Get in writing a commitment of a11 No. 1 people to vote for you. There is word that if there was a small majority of No. 1 men in the legislature, they would hold up the vote by being late and not cooperating. 34

White was one of several to warn Chamberlain of the impending conflict. The Oregonian, in another of its reverse statements, declared the people voted for the Governor out of a desire to show disapproval for Statement No. 1. Yet it was the people who, by a large majority, had approved the pledging of legislative candidates to respect the people's choice. P. B. Savoy, a friend of the Governor, said either the Oregonian's logic was pretended, or the people were crazy. If the Oregonian's conclusion was correct, he said, then U'Ren should have been busy with an amendment providing that all candidates receiving the minority vote for office be declared the people's choice. 35

Aside from the Oregonian's logic, Chamberlain, after his June victory, sent his college friend Jensen payment for his help with the reply to U'Ren's letter. The Governor said, "I feel that what we did that night called forth from Mr. U'Ren a letter that cost Mr. Cake a great many votes." Chamberlain then wrote to Lincoln Steffens complaining about how neither Cake nor U'Ren openly advocated the election of No. 1 candidates for the legislature after the April primaries. He said the legislature would have six or eight more No. 1 members if they 
had helped. Of course this charge can not be established, because Chamberlain was smoothing over a disturbed conscience. He reasoned that if he had followed U'Ren's suggestion and withdrawn, Cake would not have put No. 1 to a fair test because he was a Republican. 36

Clearly, the Governor was worried about the Republican corruption fund everybody was talking about. He may have been thinking U'Ren's advice was the best. His rationale about Cake was not logical either because his charge that Cake had always been a machine man was never clearly established. Diplomatically, Steffens did not enter into the feud between the Govemor and U'Ren. He told Chamberlain U'Ren had also written to him accusing the Governor. Steffens said they were doing a good job, and the people thanked them both.

To add to the Governor's troubled thoughts, Charles Chance, an Oregon lawyer, expressed concern that none of the newly elected Republican legislators elected in support of No. 1 had placed themselves on record as still being in favor of No. 1 . His concern was compounded by Cake not urging all of his party's legislators to honor the people's choice. 37 Chamberlain must have felt a little like Job. Next, he received word from $R$. A. Coples in Chicago, where the Republican National Convention was meeting. Coples reported Fulton was on the National Committee and trying to defeat the Governor. The National Committee was reported to have pledged help for Fulton. Fulton was recorded by Coples as saring, "Statement No. 1 can be broken, if not for myself, then for some other Republican."38 According to Coples, Fulton had the assistance and advice of the shrewdest politicians in the Republican party. Senator Nathan Scott of West Virginia, and Mr. J. Hitchock, Chairman of the party, pledged a11 the necessary funds. 
While Republicans were working on the platform for the Presidency, Coples said a detailed plan to defeat Chamberlain and Statement No. 1 was formed. The plan specified that signers of No. 1 would be given an excuse for breaking it. Fulton would see that Scott, through the Oregonian, would claim Fulton was repudiated in the April primaries on grounds of fraud. Scott would claim that nine tenths of the Democrats registered as Republicans, and thus defeated Fulton. Fulton would be held as the real choice of the Republican party, and not Cake. A careful selection of twelve to fifteen key Republican state legislators would be made. The newspapers in their districts would be purchased, if necessary, to urge all legislators to vote for Fulton. From the start, Republican leaders believed that in the legislature Cake could not gain the following that Fulton could.

Chamberlain, upon hearing Cople's report, said that if No. 1 were defeated in the legislature, there would be revolution in the state. The Governor acknowledged that some Oregon papers were bought by the Republicans. O. P. Cashow, a Roseburg lawyer, in an October letter, complained about the filth being published in the Brownsville Times. He believed Fulton started the "dirty work." Cashow was concerned and wanted to help the Governor. Chamberlain replied that he had not paid attention to the Brownsville Times. He said the legislature, in selecting the next United States Senator, would not listen either. These brave sentimpnts did not express the Governor's true feelings. 39

The Oregon City Courier declared the way was being paved by part of Oregon's press for a desperate effort to circumvent the people's will in the January legislature. People's minds, the paper said, were being 
prepared for a take over of popular liberty. A positive note was sounded by saying the people's will would prevail. 40

In mid-September, word came that Senator Bourne was coming to Oregon to declare that the legislative members had better hold to Statement No. 1 and elect a Democrat, Chamberlain. 41 This had impact because there was not a Bourne organization in Oregon, and he could not be linked to the state's Republican Machine. Even while Republican papers were hitting No. 1, Bourne's visit inspired some observers to feel he would have more effect than the Machine.

The Governor continued to receive inquiries of what voters could do to fight the Republican Machine. There was fear and uncertainty in the state. U'Ren's prediction that Chamberlain's election would bring ruin to statement No. 1 seemed almost certain. This fear brought U'Ren and Chamberlain closer together than they had ever been. The Governor donated a small sum to the People's Power League, and told U'Ren he believed the desperate effort to defeat him in January would fail. U'Ren replied:

I did all I could . . to defeat you, but I still believe... that who is chosen Senator is of little importance at this time, but it is of the utmost importance that the people should choose and that the legislature should unquestioningly obey their instructions. 42

True to the plan, Fulton charged that Democrats falsely registered as Republicans and voted for Cake in the April primaries, and for Chamberlain in June. This, of course, was part of the plan devised during the Chicago Republican National Convention. U'Ren was troubled because this charge cast a bad reflection on the direct primary law. The law was intended to protect voters of every party from interference 
by members of other parties during prinaries. U'Ren made a careful study of voter registration and election returns and announced there was no indication that Democrats had registered falsely and voted Republican in April. Fulton's charge was well known, and suspicions were high. U'Ren then publicly asked others to make the same investigation. 43

Attention quick1y shifted to Salem and the January, 1909, legislative session. Both the Republican Machine, headed by Ernest B. McHard of the Republican National Committee, and the People's Lobby, consisting of Oregonians from all over the state, were present in the state capitol. McHard conferred with most legislators, attempting to persuade them to repudiate Statement No. 1. As mentioned, Fulton supporters voted for Chamberlain in June with the belief the legislature would rule out No. 1 and elect Fulton. However, between June, 1908, and January, 1909, U'Ren and his forces also talked with every legislator, showing them the wisdom of adhering to No. 1. Legislators clearly understood the consequences if they opposed Statement No. 1. As a result, McHard found his work difficult. When the roll was called, many pledged Statement No. 1 Republicans rose and said Chamberlain was not their choice, but that they felt compe11ed to respect the people's wishes.

Chamberlain won. Between both houses, he won fifty-three out of ninety votes. This was the greatest triumph of U'Ren's career. Statement No. 1 now belonged to the people, and they would never let it go. It had taken years to bring Oregon government to the point of respecting the private voter over the Machine and industry. $U^{\prime}$ Ren was 
the engineer through the whole process. The action brought fear into industrial circles and helped to compensate U'Ren for giving up any chance for the Senate and for electing a man he did not respect. He took comfort in the knowledge that his sweeping program was closer to its ultimate goal, the adoption of the single tax.

Chamberlain's success startled the nation, and state after state examined the Oregon System. The popularity of Statement No. 1 quickly spread. By 1910, the Boston Herald reported that fourteen out of thirty Senators were chosen by popular vote. 44 Senator Borah, defeated by the Idaho legislature, but elected by the people four years later, led the Senate fight for the Seventeenth Amendment, or direct election of Senators. U'Ren took an important part in the national debate over No. 1. His triumph was a visit with President Woodrow Wilson. U'Ren convinced the President that Statement No. 1 was moral, and should be part of the Constitution. In his inaugural address of 1913, President Wilson called for the direct election of all Senators.

\section{V1. REPUBLICANS RIDICULE PEOPLE'S RULE}

After the legislature elected Chamberlain, he was besieged with many letters of congratulation. A La Grand attorney, E. E. Cockran, observed the election was a demonstration to interests that money could no longer be used to flaunt the people's will. Cockran reinforces his position by sying the people would not have let the legislators get home safely if they had refused the voter's will. 45

In an editorial conceding Chanberlain's victory, the Oregonian declared its refusal to act with the Republican Party if it did not 
reject Statement No. 1.46 But No. 1 was safer than ever before, because it now belonged to the people. However, special interests were more determined than ever to destroy it and other basics of the Oregon System, such as the initiative and referendum. Fraud and money were to be their tools. These interests scoffed at the people's ability to write their own laws. While the people stood their ground, inroads after the 1912 election were evident. U'Ren, of course, was alert and prepared to keep the issues before the people in the most striking manner possible.

On the same day Chamberlain was elected in the legislature, the counter reformers were busy. Representatives Bean and Brooks introduced a bill making it illegal to take any form of pledge from any private citizen. The "crime" would result in a misdemeanor charge, and on conviction, the penalty would be imprisonment for not less than six months in county jail, or a fine of not less than $\$ 500.00$, or both. The rationale was that any convicted person, if elected, would not be fit for public office. Bean and Brooks were inspired by similar successful reactionary legislation in Washington State. 47

The Oregonian supported the bill because it was a protest against the assumption that a few, representing themselves as the people, could force their will on elected officials. The paper contended No. 1 did not represent the majority's wil1, while putting minority fads above the welfare of the whole state. The Oregra City Courier charged the Oregonian with attempts to corrupt the people's and the legislature's morals. This, the Courier said, was one of the most abhorrent facts in the history of journalism. 48 In spite of Oregonian pressure, the bill failed. 
During the period, this contention was fundamental to all of the Oregonian's arguments. Special interests maintained minorities had no rights. U'Ren opposed this, as revealed in another chapter, by his carefully designed legislation to give all minorities a voice in government. Interests believed minority rights made goverument impractical and cumbersome. U'Ren realized this, but discovered alternatives eliminating much of it, while creating confidence in government. Developing government in which people had confidence was more desireable to U'Ren, than the risk of having cumbersome government. Of course reformers believed anything preventing special interests from raping Oregon of its wealth was worth most risks.

Confidence was an interesting dimension. U'Ren believed government could not be efficient if the public did not have confidence in it. Without confidence, voters would not trust government's laws or its attempts at change. Efficient government and confidence were parts of a complete circle, one dependent on the other. U'Ren believed adoption of an efficient form of government was one of several ways to build confidence. Confidence resulted from proof of the process. Thus, to get the process, $U^{\prime}$ Ren went out of his way to remain moral, so the people would first trust him, and secondly, his proposals. Governmental efficiency was also dependent on a sound, equal tax, such as single tax. of the two, governmental efficiency and single tax, the latter was more important to $U^{\prime}$ Ren, because it was the only way to completely release the hold that private interests had on the public. However, single tax could not be efficient if there was inefficient government. Without a government equally representing, with complete confidence, a11 people, 
al1 minority opinions, it would be difficult to establish a tax equal to al1 people and minorities. 
FOOTNOTES FOR CHAPTER I

10regonian (Portland, Oregon), December 15, 1911, p. 15.

20regon Daily Journal (Portland, Oregon), Apri1 28, 1908, P. 2.

${ }^{3}$ Daily Coos Bay Times (Coos Bay, Oregon), February 4, 1908, p. 2.

${ }^{4}$ Oregon City Courier (Oregon City, Oregon), January 17, 1908, p. 4.

${ }^{5}$ Ibid., January $31,1908, p .1$.

6Ibid., February 7, 1908, p. 1.

7Letter, Governor Chamberlain to Clara Waldo, February 10, 1908 , Oregon Historical Society, Chamberlain MSS, 1025. Ibid.

8Letter, Governor Chamberlain to Clara Waldo, February 17, 1908 , Ibid.

${ }^{9}$ Letter, Governor Chamberlain to B. F. Irvine, February 13, 1908,

10Letter, Governor Chamberlain to J. E. Lathrup, February 19, 1908, Ibid. Ibid.

11Letter, Samuel White to Governor Chamberlain, February 24, 1908 ,

${ }^{12}$ Oregon City Courier, February 28, 1908, p. 1 .

${ }^{13}$ Oregonian, March 9, 1912, p. 11.

14 Ibid., March 16, 1908, p. 9.

15Letter, Governor Chamberlain to Samue1 White, February 24, 1908, MSS, 1025. Ibid.

16Letter, Samue1 White to Governor Chamberlain, February 26, 1908,

17 Oregon City Courier, March 6, 1908, p. 1 .

18 Letter, Alex Setton to Governor Chamberlain, March 6, 1908, MSS, 1025.

${ }^{19}$ Oregon Daily Journal, March 15,1908, p. 8. 
${ }^{20}$ Oregonian, January 23,1908, p. 10 :

21Letter, E. E. Wilson to Governor Chamberlain, April 6, 1908, MSS, 1025.

22Letter, Governor Chamberlain to Oscar Hayter, March 31, 1908, Ibid. Ibid.

23Letter, Governor Chamberlain to Lincoln Stevens, May 25, 1908,

24Letter, J. D. Bain to Governor Chamberlain, April 20, 1908, Ibid.

25Letter, C. J. Curtis to Governor Chamberlain, Ibid.

26Letter, Governor Chamberlain to Rev. Frowin Epper, May 1, 1908, Ibid.

${ }^{27}$ Oregon City Courier, April 10, 1908, p. 1.

28Letter, Lincoln Stevens to Governor Chamberlain, May 19, 1908, MSS, 1025.

${ }^{29}$ Letter, Governor Chamberlain to Lincoln Stevens, May 25, 1908 , Ibid.

30Letter, W. S. U'Ren to Governor Chamberlain, May 24, 1908, Ibid.

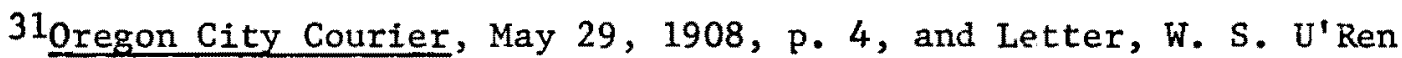
to Governor Chamberlain, May 29, 1908, Ibid.

32 Burton J. Hendrick, "Statement No. 1," McClure's Magazine, September, 1911, pp. 502-13.

${ }^{33}$ Letter, W. S. U'Ren to G. Cathorn, June 2, 1908, MSS, 1025.

${ }^{34}$ Letter, Sam White to Governor Chamberlain, June 2, 1908, Ibid.

35 Letter, P. B. Savey to Governor Chamberlain, June 5, 1908, Ibid.

36Letter, Governor Chamberlain to Lincoln Stevens, June 11, 1908, Ibid.

37Letter, C. H. Chance to Governor Chamberlain, June 5, 1908, Ibid. Ibid.

38 Letter, R. A. Coples to Governor Chamberlain, June 12, 1908,

${ }^{39}$ Letter, Governor Chamberlain to O, P. Caslow, October 5, 1908, Ibid.

${ }^{40}$ Oregon City Courier, September 4, 1908, p. 4. 
41 Ibid., September 18, 1908, p. 4.

42Letter, W. S. U'Ren to Governor Chamberlain, August 31, 1908, MSS, 1025 .

430regoil City Courier, Janue y 8, 1903, p. 4.

${ }^{44}$ George $H$. Haynes, The Senate of the United States, Vo1. 1 (Boston: Houghton Mifflin Co., 1938), p. 104.

45Letter, E. E. Cockran to Governor Chamberlain, January 20, 1909 , MSS, 1025.

46Letter, K. 0. E11iot to Governor Chamberlain, January 20, 1909, Ibid.

47 Oregon City Courier, January 29, 1909, p. 4.

48 Ibid. 


\section{CHAPTER II}

\section{U'REN'S PROPOSALS FOR EFFICIENT, REPRESENTATIVE \\ GOVERNMENT : 1909 TO 1912}

\section{VOTERS CONSIDER BASIC CHANGES}

During the early part of 1909, U'Ren and his supporters formulated their strategy for the forthcoming single tax campaign, and planned additional reforms designed to improve the operation of Oregon's government. During August, 1909, 7,500 copies of a pamphlet, simply called Introductory Letter to A Bill and Amendments, were sent to Oregon voters. The pamphlet printed names of eighteen well known families who approved the proposals. In the introductory letter, U'Ren asked voters to consider the measures and to inform him of their opinion. He asked for suggestions on any aspect of the measures that needed changing. U'Ren said the amendments would be ready for the November, 1910, general election.

U'Ren explained the amendments were designed to round out the Oregon System and to insure Oregon of fair and economical govermmental operations. He appealed to the voters, if they approved of the ideas, to reply, so another league could be formed to work for the campaign. "We desire to form four or five hundred people to work. We call on past helpers in the People's Power League to form the People's Progressive Government League."

It was explained that Oregon had forty-seven boards and Commissions to carry out the state's business. Each was independent of the other 
and of elected officials. U'Ren said no business would operate in that manner, and that more efficient checks had to be made. U'Ren and his supporters proposed to print an official Gazette, at sixty cents per registered voter, to inform the public of developments in government. Another desire was to make the initiative and referendum more effective and to prevent action from secret legislative committees. Beyond this, U'Ren believed the governor's powers had to be strengthened.1

Recipients were told they paid eight and one half million dollars in taxes per year, or sixty eight dollars per person. Those funds, U'Ren wrote, were not properly used. As a result, the average man considered the legislature a public enemy. Farmers and businessmen got as much good from forty or sixty cents as the state did from one dollar. The emergency clause was attacked because the legislature used this for extravagant appropriations. Thousands of dollars were wasted by "state emergencies." U'Ren suggested the federal form, with additions from British government, would be more economical for Oregon. Because the initiative, referendum, and recall were patched into the Constitution, U'Ren wanted to work out a logical relation between the people's rule and the legislature. The plan would permit eight per cent of the registered voters to get an initiative on the ballot. Five per cent of the registered voters would permit a referendum. The referendum would apply to any Constitutional amendment, and no act of the legislature would become law for ninety days. The ninety day waiting period would give opportunity for public review through the official Gazette and provide possible referendum action. With the reca11, twenty-five per cent of the voters could remove one or all of 
the legislature. Members of both houses would be elected to six year terms. To allow minority protection, one sixtieth of all votes could . select a representative, and one thirtieth of all votes could elect a senator. Also, names could be written in on the ballot. Legislative vacancies would be filled by the man with the next highest vote count. Officers of both the house and senate were not to be from the elected body, and thus, they would not have a vote. To do business in the house required a two-thirds majority, and in both houses, a ten dollar fine was charged for missing a roll call. Annual sessions were provided for, and legislator's desks were to be on the floor for the people's inspection.

"People's. inspectors of govermment" were suggested. Three full time inspectors would be elected to a two year term. When in session, one inspector would be in each house, and all three would inspect state and local government. One legislator could require the inspectors to investigate and report on any function supported by public funds. The inspectors would publish all aspects of their work in the oregon Official Gazette. The Gazette was to print all reported discrepancies and government documents. It was not to be used for malicious or partisan use, and the magazine would be mailed to voters bi-monthly. U'Ren also wanted to extend the direct primary law. The law would be amended to include presidential nominations. Voters could select their choice for their party's candidate for President and VicePresident. Opportunity was provided to elect the presidential electors, and those going to their party's national nominating conventions. The extended law pemitted payment of travel expenses to the convention, but not more than $\$ 200.00 .^{2}$ 
In U'Ren's view, courts needed reforming. In civil cases, proposed amendments provided that a verdict could be rendered by three-fourths of the jury. A re-trial was prohibited if there was any evidence to support the original verdict. The Supreme Court would be bound to the lower court's verdict, unless the lower court made a gross error. Judges of a11 courts would be elected to six year terms, and the Supreme Court's jurisdiction would be increased.

U'Ren's pamphlet created a stir. Some were amazed that he could produce such a volume of work and ideas, but U'Ren had hard working and loyal supporters. Without delay, the Oregonian blasted his latest effort as U'Renism. The editor believed the grave problem was that minorities would have too much power. The Oregon City Courier defended $U^{\prime} R e n$, and said the Oregonian was disturbed by the proposed changes in the balance of power. The Oregon City paper reasoned the Oregonian was in a death struggle to complain about minority rights. U'Ren was declared the voice of the people, and a strong instrument through which the program could pass. The people, the Courier said, had seen fit to wage war. The Oregonian was a "disgruntled Republican," who did not know freedom from misrule. In conclusion, the Courier declared Oregonians would not accept misrule any longer. ${ }^{3}$

Reactions to the pamphlet were signs that the November 1910 , election was hotly contested. The enemies of refom were close to an uprising. The Republican Machine was particularly unhappy with proportional representation suggested in the proposed amendment permitting onesixtieth of all votes to elect a representative, and one-thirtieth of a11 votes to elect a senator. The initiative and referendum were labeled 
experimental legislation. Reformers countered, pointing to business experimenting in attempts to increase wealth and comfort at the expense of labor. Special interests said voters did not have time to study the initiative and referendum measures before elections. U'Ren's forces showed that the law provided for fourteen and one-half days to study initiative items and longer to study referendum items. They compared this with the "Great Burden" of the 1909 legislature. On this occasion, the legislature dealt with 626 measures in twenty-eight days, which came out to twenty-two measures per day, as opposed to the fourteen and one-half days voters had to study initiative measures.

Objection to the expanded direct primary law was raised. Counter reformers complained delegates to national conventions represented political parties and not voters. Thus, they said, tax payers should not pay their expenses. The measure was derided in the May 3, 1910, Oregonian as "another freak measure intended to complete an anti-convention hobby in this state." Senator Boume, who helped U'Ren with the expanded law, said the election of party delegates simply puts power where it should be, in the people's hands. Bourne supported his statement by reminding everyone that often the national machine picked out state delegates for the national convention to favor one Presidential candidate or another. 4

In its annual meeting, the State Bar Association investigated the initiative measure providing for the Gazet:e. Lawyers from the public service corporations conducted the investigation and advised the Association to oppose the Gazette. On this recommendation, the Association voted against the measure. 5 The Bar Association failed to 
realize that U'Ren was desperate about one sided newspaper coverage. The Gazette would effectively prevent voters from getting only one view. Reformers were seriously handicapped because truth was kept from the public. James Hill, owner of the Great Northern Railroad, was accused of buying newspapers in Oregon, so news would favor railroads. Standard Oil was said to manage the news through its ownership of Associated Press. An example of Standard Oil's news management was coverage of Multnomah County Court's declaration that the initiative and referendum were unconstitutional. However, when the Oregon Supreme Court overruled the county court, the Associated Press suppressed the story.

In the middle of 1910 , the public became aware of one reason why U'Ren was interested in proportional representation. A little known bi11 from the 1909 legislature surfaced. It was voted to submit a measure to the public providing for one representative and one senator from each district regardless of population. If passed, the bill would dash any hopes of minority representation. The bill got through the legislature by a wide margin. Favorable arguments ranged from proportional representation interfering with party politics to government not having time for minority requests. 6

\section{THE 1910 ELECTION REVEALS VOTER CONCERNS}

When the 1910 general election took place, the voter had to consider thirty-two neasures. Nine were submitted by the 1909 legis1ature, and twenty-three were initiative petitions. It took nine minutes to read just the tities on the ballots. Voting was a hard job, 
but there was a heavy turnout. In spite of fears over illegal voting, U'Ren's Corrupt Practices Act, passed in 1908, ruled the "holy day."7 No argument was allowed at the polling places, there was not any vote buying, and no one transported voters from one place to the next. of the thirty-two measures, the "ballot-booth lawmakers" enacted nine and rejected twenty-three. The legislative scheme to provide one representative and one senator from each district failed. The expanded direct primary 1aw, including the vote for President, Vice-President, electors, and delegates for national conventions, passed by a narrow margin. A measure establishing the People's Inspectors and the Official Gazette failed by a wide margin. One measure, including expanded initiative, referendum and recall powers, restrictions on the emergency clause, proportional representation, regardless of districts, annua 1 sessions, and the ten dollar fine for failure to meet a roll call failed. U'Ren's initiative for court reform passed.

Why the public rejected the ballot measure including expanded initiative and referendum powers is not clear. The ballot measure included items that voters opposed, such as annual sessions of the legislature. Special interests and Repub1icans especial1y campaigned against proportional representation and the minority provisions of the expanded initiative, referendum, and recall measures. Direct legislation had proven conservative. Voters apparently favored the status quo, without drastic governmental changes. Court reform passed because courts seemed more removed from the people than other branches of government. The election of 1910 showed a trend that Oregonians were willing to go only so far with reform, and that counter reformers 
influenced voting in areas where they concentrated their propaganda. Several critics said many measures were turned down because voters did not understand them. ${ }^{8}$ While this may be true, it seems more reasonable that voters chose to vote the way they did, because between U'Ren, labor, business, and the Grange, the public knew what the issues were.

After the election, papers received letters complaining about the size of the 1910 ballot. Segments of the public asked Oregon leaders to use restraint in using the initiative and referendum. Political scientists believed popular legislation would lose support if something was not done to prevent measures that had irresponsible backing. A few supporters of reform believed the ballot was "flooded" by initiative measures to confuse voters and to take votes from U'Ren's bills. Leaders of the people's rule were not blind to the ballot problem. They felt the short ballot and the people's rule had to work together for effective government. Refomers argued that county measures, and bills to support local normal schools should not be on the state ballot. Others urged improvement in title writing, and the simplifying of issues. ${ }^{9}$

While it is true much of U'Ren's key governmental reform measures were defeated in 1910 , he carefully listened to the state wide debate on the use of the initiative and referendum and the need for ballot reform. He had always believed the initiative and referendum should be emergency powers, but he was having difficulty in passing basic reform laws permitting this. As strategy was planned for the 1912 election, he pondered how the pub1ic's concern could be merged with his. By 
merging concerns, perhaps everybody would benefit by adopting the basic governmental reforms.

\section{THE SECOND CAMPAIGN FOR BASIC REFORM}

Throughout 1911, U'Ren and others worked out new proposals for government reform. Early in January, 1912, a pamphlet was ready for the public. It discussed amendments for representative government, the short ballot, proportional representation in the legislature, and majority election of officials. This pamphlet reemphasized some of the issues the earlier pamphlet discussed. However, new issues were added, and the suggestions were far reaching. U'Ren was attempting to meet public demands and satisfy his own interests.

U'Ren's People's Power League sent out 50,000 copies of the 1912 pamphlet. The pamphlet revealed that a well known Portland reformer and state senator, Ben Selling, was President of the new People's Power League formed for the 1912 election year. Membership in the League included Senator George Chamberlain, with 112 other members, but Senator Bourne was not 1isted. In the introductory letter, U'Ren again asked for replies to the ideas. He indicated the final draft would be submitted to the public in April for enough signatures to authorize the Secretary of State to put it on the November ballot.

The pamphlet detailed expanded powers for the governor. His authority would be beyond the President's. The governor had the right to introduce, speak and vote for bills in the legislature, and had the exclusive right to introduce appropriation bills. The legislature was given the right to examine the governor and every other state 
officia1. The league believed these amendments were complete, while providing for even better government than the 1910 measures provided for.

Governor Oswald West, elected in 1910, contributed a letter showing that with U'Ren's proposals the cost of government for 1913 could be cut in ha1f. To do this, a11 unnecessary legislative appropriations would have to be dropped, and businesslike methods applied to all state departments. Departmental reorganization was necessary, and Governor West believed these changes save money and insure al1 state institutions of the funds they needed 10 without the hated emergency appropriations by the legislature. Much of such money found its way into private pockets.

The proposal reached into county government. A county's budget was to be appropriated by the voters every year. The governor was to appoint a sheriff and district attomey for each county. Any salary increase, including the deputy sheriff, was subject to a vote of the people. These officials were subject to the recall, even though the people did not elect them. After a recall, the governor was to appoint another person, but not the one recalled. County home rule was permitted. Any city and county with a population of more than 100,000 population could merge into one government. This arrangement could start either by the people's initiative or by the legislatures. If union government was initiated by the legislature, the people had to make the final approval.

The short ballot was proposed. At the 1913 general election, and on every fourth year after that, the governor, state auditor and 
members of the legislature would be elected. To insure that a11 officials were elected by the majority vote, the ballot had three columns. The voter would mark his first, second, and third choices, but mark only one column for one candidate. The winner would be determined by the candidate having the largest number of accumulated votes. In the event of a ti.e, the winner would be the candidate having the largest number of first choice votes. The short ballot would insure that no voter had to vote for more than five offices at one time. In 1910, some counties had asked voters to make decisions on over 100 office seekers.

In his pamphlet, U'Ren asked voters to consider abolishing the senate. He proposed the legislature should be one house, known as the assembly. Districts would be arranged so one sixtieth of the voters could elect a member to the assembly. The proportion was the same as that for the house in the 1910 initiative measure. The one-sixtieth proportion, based on the 1910 census, would permit the assembly to have sixty members, while attempting to meet the special interests concern of minority representation. Annual sessions for the assembly were required. The presiding officer of the assembly would not be an elected member. This officer would not appoint standing committees, or have a voice or vote on assembly business. He could have any other powers the assembly wanted to give him. The ten dollar fine for failure to vote was, of course, familiar. Also, the new proposal reduced the term from six years as in the 1910 proposal, to four years.

A majority of the assembly could call a special session, while the 1910 provision was kept permitting recall of one member, or of the 
whole assembly. Whether one member or the whole assembly was under reca11, operation of the assembly was suspended unti.1 the procedure was completed. Under a recall procedure, the assembly could only act if there was an insurrection or natural calamity, and under these conditions, only the governor could call the assembly. The gubernatorial candidate who lost on his party's ticket, but who had the largest number of votes among the losers, was an ex-officio member of the assembly. He was, of course, under all the regulatory laws. In this provision, it is clear to see U'Ren's desire to provide for, as far as possible, minority rights.

The governor would select his own cabinet consisting of the attorney general, secretary of state, state treasurer, state printer, superintendent of public instruction, secretary of labor, and the state business manager. He would have complete control of organization and management of all state institutions, state business, and public functions that were currently controlled by boards and commissions. One exception to governor control was the railroad commission, but the governor was to appoint commission members. Not only was the governor a member of the assembly, but also his cabinet were members. While the governor introduced money measures, the assembly had power to reduce the amount. However, the assembly could not exceed the governor's request without his consent. While in the assembly, the governor and the cabinet would answer all questions in rriting.

The plan was staggering because the changes would alter government beyond what most people could comprehend. This was the ultimate of U'Ren's political thinking. One thing was certain, the plan was 
presented only after careful thought, only after every alternative was thoroughly studied. U'Ren was an astute student of government. His plan represented the best of his knowledge and understanding. U'Ren felt he had guaranteed every minority group representation, every citizen fair and equal treatment. U'Ren believed the most economical form of government had been devised, while providing members to create voter confidence. With this plan, he estimated Oregonians would get one dollar and fifty cents worth of service for every dollar that was currently being spent.

The activities of the 1911 legislature provide good reasons why U'Ren felt justified in presenting voters with his comprehensive plan. More than half of the legislative members tried and succeeded in getting money for public institutions in their district. The usual $\log$ rolling methods were used for these unnecessary appropriations. The state did not have a department to guarantee taxpayers the appropriated money was spent for what was intended. 11 These actions had generated disgust and alarm among Oregon's electorate.

Counties were in the same condition, with no delegated authority to govern funds. The sheriff and other elected officials were almost independent. County levies to bring in running expenses, and the legislative appropriations, were agreed to in a back room for the entire state during each legislative session. There was not a law limiting the total public incone for the state. There was not any adjustment of the ends to fit the means, because Oregon government operated on the theory that there was not any limit to the means. U'Ren knew that under these poor conditions, single tax would have difficulty 
in guaranteeing the state income would be used wisely. While single tax had the potential of lowering taxes for the average person, the lack of basic regulation would weaken that potential. This fact was an important reason why U'Ren favored county level tax collection for his single tax proposals in the event that the governmental reform bills failed.

In commenting on the county provisions, U'Ren said voters would elect three directors, who, in turn, would select a business manager. The manager would hire all other county officials, as a general manager in American business. Directors would only be paid expenses, and were charged with seeing that the manager was efficient. 12 U'Ren envisioned the county business manager having a lifetime job, which to a degree, would guarantee efficiency and economy.

With respect to the legislature, U'Ren wanted to avoid a situation forcing the assemb1y to pass 1,100 measures in forty days, with each work day only lasting four or five hours. Continuing, U'Ren said:

I surely cannot be said that government by the people is fully successful, until they actually receive a hundred cents worth of public service for every dollar of public money expended. The people of Oregon are the supreme power now in the making of laws and in the nomination as well as in the election of their public officers. Logically, the next step is to devise a plan of government that will give the highest possible efficiency in the public service.13

In considering the proposed short ballot providing for majority election of officials, the 1910 gubernatorial race caused concem over how representative government truly was. U'Ren felt a sense of urgency to provide voters with an alternative to what happened in 1910 . The contest had many dimensions, which makes precise interpretation difficult. There were three forces at work, counter refonners, reformers, 
and a league between Chamberlain and Bourne, which was the most obscure. The third group contained reformers who desired to use progress as a guarantee of continued public office. It will be recalled that neither Bourne or Chamberlain had strong organizations, and Bourne had to face the voters in 1912. All of these factors produced a governor elected by a minority vote. To U'Ren, this was intolerable for a true republic. Counter reformers supported Republican Jay Bowerman, who was acting governor. The exact nature of this support will be supplied in another chapter. Reformers, including U'Ren, supported a Republican for governor, Grant B. Dimick. Dimick was a former Clackamas County judge. Toward the end of the campaign, the third group emerged in support of Oswald West. Jay Bowerman was respected, because he clearly stated his position. Bowerman was opposed to the Oregon System, and publicly said the people were unable to legislate through the initiative, referendum, reca11, and Statement No. 1. Reformers predicted that should Bowerman be elected, he would have a statewide Republican Machine built within months. With Bowerman, it was a clear question of the new against the old. Bowerman was frightening to reformers, because he was popular, and there was the possibility of his winning. In the beginnings of the 1910 campaign, Bowernan's prospects were additionally favorable because reformers showed signs of splitting their vote among several candidates. Some refomers and U'Ren appealed to Republican political leaders and voters to support Dimick. They believed Dimick was the strongest candidate against Bowerman. Those reformers who were interested in entering the race were asked to sacrifice their desires and support Dimick in the interest of the oregon system. Several respected contenders did back out. 14 
On the Democratic ticket, Oswald West was in the lead, but appeared weaker than Dimick. The charge was laid that Senator Bourne and Senator Chamberlain, members of opposite parties, were cooperating in a quiet effort to insure West's election. They intended to use West in setting up their own reform oriented machine. The Senators were encouraging men to run in support of reform in the Republican primaries in an effort to draw support from Dimick. This would insure that Bowerman would win over Dimick in the Republican primaries by minority vote, while West would win in the Democratic primaries. The voters would then have a simple choice at the general election, Oswald West. The Oregon City Courier said the plot was creating "merriment in quiet circles in Portland."15

In August, while Dimick was making a campaign tour of Oregon, several minor Republicans declared for the gubernatorial race. One of them was Colonel Hoffer, editor of the Salem Journal. He said his campaign was in support of the Oregon System. This was a surprise, because on July 1, 1904, he wrote an article opposing the direct primary, and showing contempt for "U'Ren's bil1."16 Reformers became more nervous when news of insurgent victories in Washington State reached them. They pleaded with Hoffer to get out of the race and help Dimick. This did not work, and Dimick felt compelled to meet Hoffer in a debate. The debate took place on September 16 in Oregon City. U'Ren presided. Hoffer tried to prove there was graft in Clackamas County while Dimick had been judge. The Colonel said the county's taxes increased because of the court. Dimick presented an effective reply, showing the county court was not responsible for the increase in school children, or the demand for better roads and bridges. 
No one really took Hoffer's race seriously. However, his unexplained expense account and expensive touring car used during the campaign cast further suspicion on the charge directed to Bourne and Chamberlain. Papers predicted the September primaries and the November general election would be a free-for-al1 to place a Portland Statement No. 1 man in the governor's chair. The primary results were as feared, because West and Bowerman won.

During October, 1910, some papers commented on the BourneChamberlain dea1. The Senators were charged with compelling the people to accept a double cross and vote for a "henchman," the tool of the "spel1binders," the chief of whom was Senator Chamberlain. Among other things, he especially wanted assurance of another term. Bourne and Chamberlain were accused of being worse than counter reformers, while forcing West on the people with a lot of maneuvering. Of course, Bowerman made good use of the reported plot. The arch supporter of Statement No. 1, the Courier, declared it would be better to vote for Bowerman even though he opposed the Oregon System. Bowerman, the paper said, had the courage of his convictions, and had given the truth about the Bourne-Chamberlain scheme. The Courier asked, "why vote for a tool of cowards who would rob votes in the dark?"17

The Courier's position brought charges of inconsistency. Several publications said the paper was not clear on its Statement No. 1 position and was both Democratic and Republican. The Courier made clear that its principle was not to support political cliques just because the candidate said the right thing. To proclaim, "let the people rule," was not enough. The people had to rule, not a clique working through the allurement of the people's rule. 
Clearly, the Courier was in a dilemma. Realistica11y, it could not go on supporting Bowerman. Reluctantly, the policy was adopted that Bowerman was the "rottener" and West was the "rotten."18 In exasperation, the paper said:

The Bourne-Chamberlain Machine will be aided by West and vise-versa, but West is the little tool of two whose clods of corruption stick to them and weigh them down like the clay laden spokes of a wheel through the black belt of Alabama, or reeking with the political stench of its stagnet green and slimy pools...19

The conclusion was that voters should support West, because there was not any hope in Bowerman. West could be controlled, the paper said, while Chamberlain and Bourne would be dealt with later. Whether the Courier had any influence or not, Oswald West was elected in November, 1910.

U'Ren's alternative provided in the 1912 short ballot would have prevented the travesty in 1910. He believed minorities had to be represented and had to make their desires known. But he believed just as firmly that the majority had to elect public officials because they represented everyone. U'Ren was confident that majority decisions on elective offices and with the basic reforms would take into account minority problens. However, the counter reformers suppressed U'Ren's views, and designed ways to realize their own wants by a minority vote. Oregon City's Enterprise spoke for the insurgents by commenting that the "people are not going to come to a state where things are too unsettled by the experimental laws proposed by a dreamer." 20 The Enterprise should have said settlers were not coming to Oregon because of high taxes created by corrupt government. Instead, settlers were going to Washington, California, and British Columbia. 
While there was opposition to U'Ren's 1912 plan, it was not debated as greatly as was the 1910 plan. The single tax issue of 1912 was a partial reason. But the annual state Grange meeting held in Roseburg during May supported U'Ren in some aspects of the proposals. The Grange's legislative committee report focused, to a large degree, on the direct primary law. Their greatest objection was that a small minority could elect a candidate who was often of poor quality. The report used the 1910 gubernatorial election as its prime exhibit. They complained of the progressive Republicans being split between Dimick, Hoffer, and one other, while Machine Republicans backed Bowerman. 21 Their solution was to adopt a short ballot much like the one U'Ren was proposing, guaranteeing that all public offices would be filled by the majority vote.

During November, Oregon voters decided, in this second attempt at: governmental reform, the fate of U'Ren's hopes. The ballot measure abolishing the senate, permitting the governor to introduce al1 appropriation bills, and holding to the one-sixtieth proportion for the assembly, overwhelmingly failed. The legislative efforts to eliminate proportional representation also failed. As the fight over the single tax issue is considered, several reasons for the defeat of basic reform wil1 become apparent. 
IW. S. U'Ren, Introductory Letter, a Bill and Amendments (Oregon City, Oregon: By the Author, Oregon City, 1909), p. 2.

2 Ibid.

30regon City Courier (Oregon City, Oregon), August 20,1909, p. 4.

4James H. Gilbert, "Single Tax Movement in Oregon," Political Science Quarter1y, XXXI (March, 1916), p. 19.

5W. G. Eggleston, A. D. Cridge, and W. S. U'Ren, People's Power and Public Taxation (Portland, Oregon: Multnomah Printing Company, 1910), pp. 33-34.

${ }^{6}$ George H. Haynes, "People's Rule in Oregon," Political Science Quarterly, XXVI (March, 1911), p. 32.

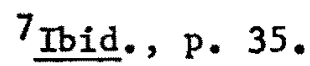

8 Ibid., p. 34 .

${ }^{9}$ Ibid., p. 36.

10W. S. U'Ren, Introductory Letter, Draft of Suggested Amendment for Representative Government (Oregon City, Oregon: By the Author, Oregon City, 1911), p. 3 .

$11_{W} . S$. U'Ren, "State and County Govermment in Oregon and Proposed Changes," Annuals of the American Academy of Political and Social

Sciences, XXXXVII (May, 1913), p. 270.

12 Ibid., p. 271.

13 Ibid., p. 273.

${ }^{14}$ Oregon City Courier, August 26,1910, p. 1 .

${ }^{15}$ Ibid., September 30,1910, p. 4.

16 Oregon City Courier, September 9, 1910, p. 1.

${ }^{17}$ Ibid., October 7, 1910, p. 4 .

${ }^{18}$ Ibid., October 14,1910, p. 4. 
${ }^{19}$ Ibid., October 21,1910, p. 4.

20 Enterprise (Oregon City, Oregon), May 27, 1912, p. 3 .

${ }^{21}$ Oregonian (Portland, Oregon), November 3, 1912, p. 2 . 
CHAPTER III

REACTION BY THE SPECIAL INTERESTS TO

SINGLE TAX AND GOVERMMENT REFORM

I. OREGON IS PREPARED FOR SINGLE TAX: 1908

In 1908, while U'Ren was concentrating on saving Statement No. 1 , the single tax was advanced as a ballot measure for the first time. U'Ren did not intend to make the single tax a great issue for 1908. The measure served the purpose of making voters accustomed to single tax and to its possibilities. Significantly, however, the a11-out effort was to come later. U'Ren disagreed with his supporters over the exact nature of the bill. E. B. Weinstein in her dissertation William Simon U'Ren: A Study of Persistance In Political Reform (1967) indicates that U'Ren desired a pure single tax bill, while other single taxers did not. However, at that time political writers and some newspaper accounts did not imply this. They assume U'Ren supported the measure. This question can only be answered when the $U^{\prime}$ Ren papers become available. I'Ren was uncertain as to how far the bill should approach a pure single tax measure. The result was a bill that only approached a full single cax policy. As efforts for single tax unfolded, it became clear that $U^{\prime}$ Ren did not think a pure single tax policy would likely be accepted in Oregon, U'Ren believed special interests could be broken by single tax measures that retained a resemblance to the existing general tax laws. 
The 1908 initiative measure was submitted as follows:

For constitutional amendment providing that all dwelling houses, barns, sheds, outhouses, and all other appurtenances thereto: All machinery and buildings used exclusively for manufacturing, and appertenances thereto: All fences, farm machinery, and appliances used as such: All fruit trees, vines, shrubs, and all other improvements on farms, all live stock: Al1 household furniture in use: And all tools owned by workmen and in use, shall be exempt from taxation in addition to exemptions now authorized by the Constituion.

The ballot proposed to exempt that form of property which was the most affected by corrupt government. Elimination of land speculation, large, profitable subdivisions, and taxation of labor products would result if the measure passed. Single taxers clearly saw benefit to Oregon farmers in the proposa1. Since much of the state was agricultural, it was vital that famers were converted to the idea. Thus in 1908, most of the efforts were directed toward them.

The Grange was a key factor in dealing with farmers. Immediately, Grangers took an unfriendly attitude to the single tax. They believed a tax exclusively on land would increase rents and the cost of doing business. They reasoned this would require labor to bear an unusually large tax burden. While single taxers did not directly address themselves to the Grange's ideas, they stressed to the farmers their gain with the exemption of improvements and belongings. 1 The benefits were often obscured by observations such as the March 7, 1908, Oregonian made. The article pointed out that different writers had different calculations of what the actual tax would be In later campaigns, U'Ren went to great efforts to counteract such criticism.

Critics, the forces of the special interests, said farmers would pay a11 the taxes. Farmers were told improvements on their land were 
worth less than improvements on city lots. This meant the proposed single tax would favor the city laborer, and push the farmer even further down the social and financial scale. Through the Granges, farmers sensed a greater awareness of their political power. They prided themselves in being informed by local Grange discussions. Any action that approached downgrading them was opposed. To add to their growing concern, critics said the tax measure would also benefit cattlemen, who were enemies of the Grange.

Single tax forces attempted to rebut these arguments by calling the existing system an outrageous toll on all industry. The amendment placed taxes squarely on land monopoly, the base of all monopolies. It was promised that the blight of landlordism would vanish. This was important to farmers, because many rented all or part of their land. Farmers were told all workers would benefit, as the tax would multiply the demand for labor in factories and on farms. Construction and distribution industries would gain, U'Ren said, because the tax would make them independent of large corporations through less prohibitive business taxes. Both of these industries were important to farmers, especially distribution, because distribution of farm products influenced the farmer's profits. Single taxers argued everyone would become more independent because the measure would permit home ownership, higher wages, and as population increased, more valuable property.

Even with these clear assurances, Grangers believed single taxers were attempting to mislead them. Distrust centered around the provision exempting manufacturing plants. Farmers charged the single taxers with covering up the manufacturing exemption, while only 
emphasizing the farm benefit. It is true that single taxers were mainly campaigning with the farmers, but no secret was made that machinery and bulldings would be exempt along with the farmer's orchards, and other related items. ${ }^{2}$ In short, the Grange was saying the measure favored manufacturing. A. N. Young, in Single Tax in the United States (1916), also saw an element favoring manufacturing. Neither the Grange nor Young fully explained their position. For some reason, farmers believed the single tax measure would force them to subsidize manufacturing, thereby creating a greater degree of special privilege.

The single tax measure did not intentionally favor either farming or manufacturing, but offered them the opportunity of equal development. It was aimed directly at speculators. Single taxers reasoned that labor value belonged to the one who created it, thus the per capita wealth belonged to the people who created it, not to the speculator. Under the general tax laws, speculators paid disproportionately low taxes and realized great profits when they sold. Every twenty acres of land held by a speculator denied one family from farming. ${ }^{3}$ The large land holdings in Oregon were slowing the state's growth, and was one reason why the single tax measure applied the burden of taxes on land values. This required the speculator to pay the same pexcentage of tax as the farmer. It encouraged the speculator to sell his land to new settlers, thereby increasing everyone's land value.

Some writers have believed U'Ren was a strict Jeffersonian, in the sense of getting everyone back to the land. This is not the situation. U'Ren saw in Jeffersonianism a way to provide every person the latitude to personally develop to the greatest possible extent. 
Jeffersonianism prevented special interests from manipulating government to hold back development of the average citizen while enriching themselves. Consequently, U'Ren desired a practical balance between manufacturing and farming. His position when announcing his candidacy for the senatorial race in 1908 clearly revealed this. His desire was to develop Oregon to its optimum with the proper balance. In U'Ren's view, single tax actually encouraged manufacturing. It made it easier for men with less capital to establish a firm beyond the control of a large national corporation. There would be fewer attempts to destroy fledging industries. In this matter, U'Ren was apart from many Progressives, while advocating Progressive measures. Although he called himself a Republican, his views were also contrary to the party position regarding the balanced position between farming and manufacturing. Republicans were having a difficult time in appearing Jeffersonian, since their policies fostered large corporations and monopolies. Their activity was seen as being at the expense of the farmers and laborers. ${ }^{3} U^{\prime}$ Ren had a soft spot for farmers, and he did what he could to show them that his program would enable them to share in the nation's growing prosperity, enlarge their political leadership, and insure them a fair profit equal to their labor.

Joseph Fels, a national supporter of the single tax, observed that Americans had a stranze sense of justice about taxation. While taxes were a burden, and often the chief instrument of oppression, they believed any exemption, however legal, made them tax dodgers. Fels believed the idea of dodging taxes worked against the 1908 single tax measure. If Fels was correct, then it equally applied to the 1910 and 
1912 elections. Any tax system, such as Oregon's general tax laws, that avoided exemptions, appealed to the American sense of justice. 4 Farmers were not only wary of the single tax exemptions, but for some inexplicable reason feared there was something more radical than what the measure actually was. They believed that the ultimate goal was confiscation of a11 land. Both the January 11 Oregonian and the May 26, 1908, Journal expressed this view. Opponents of the single tax played this up, especially in the elections of 1910 and 1912. The Grange believed a broader tax base than just land was needed to eliminate the possibility of confiscation. Neither were farmers willing to believe that land always increased in value as single taxers promised. Instead, they favored apportionment according to wealth or income. It was argued that personal property benefited more from police and fire protection than 1and. Thus, personal property should be taxed. Grangers were not alone in these beliefs, but they were urged upon them by special interests who knew differently.

During the 1908 campaign, there was little doubt among the voters that the personal property and improvements exemption measure was a step towards single tax. This is important to remember, because in later campaigns the opposition charged U'Ren with trying to secretly establish the tax. The February 14, 1908, Oregon City Courier printed an editorial from the Johnstown Democrat, a western Pennsylvania daily. The editorial said the proposed tax law was a concern to the whole nation, and if passed, Oregon would have an advantage over California and Washington. The Democrat calculated that Oregon could sel1 products at two per cent below other states and make the same 
profit. The 1908 Voters' Pamphlet freely admitted the measure was single tax oriented. The pamphlet's statement went on to say that Oregon's general tax laws encouraged monopoly and discouraged industry. Oregonians considered the tax proposal, and at the general election, U'Ren received their answer. The results were predictable. The bill went down to a serious defeat, with 32,066 yes votes, to 60,871 no votes. Only Coos County carried the measure. This was an area on the cost which was dependent on the timber industry. Multnomah County, the most urban area, defeated the measure by a comparatively narrow margin, 10,828 yes votes to 11,311 no votes.

Ordinary political leaders would have been discouraged and would have likely dropped the whole plan. U'Ren, however, did not look on the results as a defeat, but as a starting place. He reasoned the voters had a knowledge of single tax, and further education, appealing to their sense of justice, would eventually lead to passage of the measure. Yet the reformer shrewdly sensed he only had a short time until the public would tire of the matter, and he badly needed financial help. He was poor because of personal donations to the People's Power League, and because of little time spent in his Oregon City law practice. To properly deal with the issue, he needed both time and money. Just how is not clear, but he discovered a solution to both problems with Joseph Fels.

Fels, cn American millionaire soap manufacturer had an office in London. He was horrified at the conditions of farmers and workers. He bought a farm in the country, thinking he would bring people out from the city, but Fels quickly discovered farm iife was not the 
solution. Henry George had been in London lecturing on his single tax, and Fels quickly realized this system was the answer. He told a friend, "It would give people access to the land by making it impossible for anyone to hold more land than he could use." 5 The results of his interest are we11 known. With his money, he helped the British, Germans, Danish, and the Australians promote single tax.

From these efforts, grew the Joseph Fels Fund Commission of America. The fund was established in early 1909, and was devoted to establishing within five years single tax in America. At the organizational conference, Daniel Krefer became chairman, and consequently sold his business. Tom L. Tohnson, a street car magnet, became treasurer, After Johnson died, A. D. DuPont filled the post. Four others were elected to the Commission. They were Jackson H. Rolston, a Washington lawyer, Lincoln Steffens, Fredric C. Howe, a Cleveland lawyer, and George A. Briggs, a manufacturer of electrical instruments. Later, C. H. Ingersa11, a watch manufacturer, joined the Commission. It is interesting that big business opposed a tax system supported by other industrialists. The inference is that big business was convinced public development had to be limited and controlled to insure undisturbed profits, while the supporting industrialists were convinced their profit growth depended on man's unbridled development.

In March 1909, U'Ren went to this Commission and explained the 1908 single tax campaign. He then described his 1910 proposal, which was agitation for a Constitutional amendment giving each Oregon county complete local option in taxation. U'Ren was encouraged by L. D. Taylor, known as "Single Tax Taylor," mayor of Vancouver B. C. Taylor had 
successfully removed the tax on improvements. As he conferred with the Commission, this factor raised U'Ren's enthusiasm which impressed its members.

By May 1, 1909, the Commission designated Oregon, Missouri, and Rhode Island as the most likely to adopt single tax. 6 oregon looked espectally promising because of its advanced Oregon System and the people's interest in government. They also felt confident that U'Ren was an able leader. If single tax were possible, U'Ren would secure it. Few, if any, progressive leaders had begun their original work with single tax as the ultimate goal. As a result, U'Ren was put on the Commission's payroll, so he could work full time for single tax.7 This was good evidence the Commission agreed with U'Ren that a pure single tax measure was impractical politics. Apparently, U'Ren remained on the payroll up to 1914. However, for Oregon, the fate of single tax was decided by 1912. After U'Ren's appointment, the Commission pledged to give one dollar for each dollar raised, and the offer stood for any locality interested in single tax.

\section{SPECIAL INTERESTS FIGHT BACK}

Special interests of Oregon were interested in people control and profit control. Their reaction stemmed as much from fear over losing political control as from losing profits. They were still smoldering over the loss of Senator Fulton. U'Ren's pamphlet promoting governmenta 1 reform enraged them. The plans formed with the Fels Commission frightened them. At first, the initiative and referendun were tolerable. However, their use to form corruption-free government and a 
tax system that favored the middle income citizen was more than they could accept. By 1909, big business and the Republican Machine were on the verge of revolt against the Oregon System.

During November of 1909 , there were foreboding indications of Republican action directed at the 1910 general election. On November 13, the Oregonian said, "all Republicans of Oregon intend to repudiate Statement No. 1. They intend to suggest in an assembly candidates for the primary and put the knife into each and all who declare for Statement No. 1." Even though Senator Bourne's term did not expire until 1912, there was early interest in that election. Special interests wanted to prepare the ground so they would not lose another seat to reformers. The statement also reveals intentions to violate Oregon law. The assembly was prohibited by the direct primary law. Before the law, it was known as a convention. The name was changed to confuse the public as to its intent. The convention dictated which party member would run for which office. The desire of the Republicans was to choose candidates at the assembly to run in the primaries. This would discourage a Republican from running if he were not selected, while the direct primary law was designed to insure that anyone could run on his party's ticket.

Mr. Cardwe11, when elected president of the Republican Assembly Club in Roseburg, said he had never had faith in the initiative and referendum. They were impossible and impractica1.8 A. C. Masters, a former state senator defeated under the direct primary law, said the initiative, referendum, and direct primary had led people to socialism. M. C. George, chairman of the Republican State Central Committee said 
he would never sign Statement No. 1. He claimed legislators violated their oath of office when they bound themselves to vote according to what others wanted. In his mind, legislators were independent of the voters. 9

At the November 24, 1909 meeting of the Portland Republican Club, restoration of the old methods for selecting Senators and state officials were discussed. To replace the outlawed convention, prospects of a state-wide assembly were considered. One brave member, Judge Henry E. McGinn, rose and spoke against the assembly plan. He declared:

I am opposed, strongly opposed to the assembly and the reversion to old conditions. The direct primary law came to us in Oregon as a result of the most corrupt politics any state had known in the Union, bar none... . You say that you are going to have an assembly. I ask you who will be there to compose it? I will tell you, the agents of the electric company will be there, the agents of the street railways and the gas companies and of the predatory trust, and combinations, and of the big railroad companies will all have seats. The men who have franchises to guard, the men who fatter off the fruits of the red light district, the men who own saloons, they will all be there. But the wage earner, the smal1 taxpayer, the merchant, and business man, the honest people of the state will not be present. How in God's name could they be? What chance would they have to be selected? 10

The meeting's reactions to McGinn's moving speech are unknown, but his remarks revealed prominent Republicans were in opposition with party leaders and financial supporters. In spite of the split, the assembly plan became official Republican policy.

Early in the new year, the Oregonian spoke of the impending Republican state assembly as the means of pulling together all the loose parts of the party. The paper said the assembly would avoid abuse of the direct primary by selecting men to run who were of the same mind. This would avoid the "go-as-you-please plan of U'Renism." 
The Oregon City Courier retaliated, predicting the Oregonian was wasting space by trying to bring back Republican Party boss rule to Oregon. "Never has there been a deeper 1ibelous effort on the part of a great journal to wrest from the people the power to make and keep a stronger, better citizenship."11

Special interests devised several ways to attack the Oregon System. The 1909 legislature adopted a bill to be presented at the 1910 general election. It provided for a constitutional convention to consider changes in state government. This matter did not become an issue until the state was familiar with the forthcoming assembly. U'Ren's forces were particularly alarmed with the constitutional convention. A convention could write out the whole Oregon System without a vote of the people. The constitutional convention had wide support, and passed by a three to two margin. 12

U'Ren's People's Power League contended it was a big business scheme to take power from the people. Big business, the League warned, wanted all rights to taxation and exemptions. The bill would have required five elections over nineteen months. This was contrary to complaints of complications inherent with the direct primary law. The bill provided the electorate with an opportunity to vote on the new constitution during April, 1911. Yet U'Ren still believed the public would not have that chance.

Between 1890 and 1910, six states had constitutional conventions. In several states, the convention proclaimed the new constitution law without a vote. In 1900 , Virginia called a convention, with a promise to allow a vote. However, the convention adjourned in 1902 without allowing public reaction. Franchise corporations and big business had 
persuaded delegates to break the promise. The Virginia Supreme Court refused to decide if the people's power was taken. Later, the court ruled the people gave the convention full powers when they voted to have one. $U^{\prime}$ Ren made good use of these examples. He reiterated that Oregon bosses were out of a job, and the reformed system was interfering with control and profits.

The People's Power League argued the people and the legislature could make all necessary changes in the constitution without a convention. Special interests could just as easily use the initiative and referendum to present their ideas to the public. The League emphasized the high cost of holding a convention, an estimated $\$ 250,000$. The same amendment would cost only $\$ 5,000$ by using the initiative and referendum. Practical politics dictated a long period of time before any certainty would develop regarding the meaning of a new Constitution, and there would be many long and costly lawsuits.

In the fight against the assembly and the constitutional convention, U'Ren eventually found an ally in the Grange. At the Grange's state convention, held in Oregon City during May, a representative of the Pamona Grange asked the delegates to declare the initiative and referendum a reserve power and avoid its over use. They argued many measures were not of interest to the public. U'Ren, of course, also believed this. His proposed governmental reforms would largely care for the problem. A delegate from the Union County Grange wanted to require fifty percent of the voters to amend the Constitution. These types of provisions were disliked by U'Ren, because they prevented effective minority expression. In his annual address, State Master 
H. J. Buxton denounced the constitutional convention because its supporters opposed direct legislation. Direct legislation was, "Worth far too much for the people to take any chances on its overthrow or its serious impairment." 13

At the meeting, called the most important Grange convention ever held in Oregon, the Committee on Legislation reviewed the assembly plan and declared it was not tolerable. They took the position that people could not have too much or too direct a power in their government. The report said the assembly, where candidates would be chosen, acted on the theory that voters were too ignorant to rule themselves. 14

Within a month after the Grange's state convention, U'Ren, and Judge Browne11, a candidate for state senator from clackamas County, were traversing the state speaking against the assembly plan. The tour was timed to begin just before the Republican county assemblies met to select candidates for the state assembly. Machine bosses were sending lists of names to the counties.15 The county bosses met with a select caucus. From the lists, the caucus selected delegates to attend the county assembly. In one county, only six met in the caucus, and selected thirty or forty to attend the county assembly. In another county, a caucus of one man met to select delegates from the lists. The county assemblies were not widely publicized, and while the semi-secret assemblies were meeting, agents from the Machine combed the state, enlisting the famers' support for the upcoming state as semb1y.

The Grange, Judge Brownell, and U'Ren were more successful in influencing public opinion than the Machine agents. In mid July, 1910, 
a careful opinion survey on the assembly was taken in Marion, Iinn, Lane, and Clackamas Counties. The survey revealed that seventy-five percent of the voters were opposed to the assembly.16 Yet as the Republicans prepared for the state assembly, they still hoped their candidates, with money and propaganda, would sway voters against the Oregon System.

Immediately after the Multnomah County assembly, the state assembly met in Portland's Armory. Just as Multnomah's assembly was directed by a secret meeting of special interests, so was the state assemb1y. Among other things, the meeting considered ways in which the Republican Machine could elect their own United States Senator in 1912. Everything had to be done to defeat Senator Bourne. Some consideration was given to electing men in 1910 on the premise of supporting Statement No. 1. During the 1911 legislature, special attention would be given to doing a good job. In 1912, these men would run on their record, and not on Statement No. 1. If enough were re-elected, they would not vote in the 1913 legislature for Bourne. As it turned out, the elaborate plan was unnecessary, because the electorate did not even elect Senator Bourne during the 1912 primaries. 17 The Machine also wanted to elect some key men to the legislature who were not No. 1 men. To do this, the secret meeting decided that in Multnomah, Clackamas, and Columbia counties, several Statement No. 1 men would run on each primary Republican ticket opposed to only one anti--Statement No. 1 candidate, the favored man. This would confuse the voters favoring Statement No. 1, and the vote would be split. Then, the Machine's man would win by more votes while never supporting Statement No. 1.18 
In late July, another meeting took place as the state assembly was about to begin. Thirteen rural newspaper editors met in Portland to merge the state's little papers into a "boosting club" for the assembly plan. Several meetings followed to consolidate the organization. J. S. Dellinger of Astoria called the meetings, and W. G. Gilstrop of Eugene served as secretary. Colonel Hoffer, a candidate in the 1910 gubernatorial race, said the assembly papers would support al1 assemb1y candidates throughout the campaign. 19

Different men who desired selection as candidates by the state assembly set up headquarters. As delegates began to arrive, they were encouraged by the candidates' agents to pay a call to the different headquarters. Jay Bowerman, who became the assembly's candidate for Governor, also established his headquarters. Almost every delegate paid him a visit, and received a good, "stiff" private talk.

As the assembly started, Harvey Scott, owner of the Oregonian, came forward as the leader of the old Republican Machine. All the big business interests followed behind him. He strongly called for abolition of the initiative and referendum through the proposed constitutional convention. 20 Selection of candidates took little time, as the bosses already knew whom they wanted.

J. Simon, Mayor of Portland, managed the assembly. One report said he played "fast and loose with the queer assembly."21

Opponents of Statement No. 1 and U'Ren's Oregon System sounded even stranger after the assembly. They declared that the measures increasing the people's rule denied legislators and other public officials the right to serve their private conscience. Now, the 
Republicans had a list of men pledged, if elected, to think the Machine's thoughts. Judge McGinn, in commenting on the assembly candidates, said the single most important thing was to defeat their ticket, as the candidates were strong believers in machine government. 22 Judge Dimick revealed that much of Oregon's press was now asking voters to select assembly candidates. Papers were saying the Machine candidates were better than those left to nominate themselves through the primaries. 23

The state was alive with interest over the conflict. Letters were published in newspapers, thoroughly discussing Statement No. 1 , the constitutional convention, and the assembly. Street meetings were frequent, where one or two hundred people would stand for several hours, as differing speakers debated the issues, and formal lectures were heavily attended. The rash of interest was compared to that in the Federalist papers, published during the debate on the Federal Constitution. 24 Thousands of pamphlets were printed and distributed. Whole pages in newspapers were devoted to political questions. Seemingly no voter could remain ignorant of the issues. The most secretive political leaders were forced to come out and show where they stood.

The climax came in November, 1910, when in private, rich and poor alike, decided the fate of Oregon. Many aspects of this critical election have been explained in the previcus chapier. The 1910 single tax measure will be discussed later. The election had power to augment or destroy the oregon System. The results of governmental reform are known. Jay Bowerman, and the rest of the assembly candidates, were 
smashed by disgusted voters. The constitutional convention suffered defeat as we11. After the election, most newspapers believed there would never be another attempt at assemblies. For other states looking on, the lesson was learned, and they knew what to expect.

During the next two years, some attempt was still made to destroy the Oregon System. The 1911 legislature submitted a bill for the 1912 election requiring a fifty percent majority vote to pass constitutional amendments. However, it failed. The larger telephone companies carried the initiative and referendum to the United States Supreme Court in an attempt to overthrow them, because of a corporation tax the Grange pushed through the legislature. The Grange and labor paid for the defense and won. The Supreme Court declared that only Congress could deal with initiative and referendum matters.

During 1911 and 1912, there was not time for the special interests to worry about the Oregon System. As will be explained, the single taxers made gains during the 1910 election, and the threat of single tax was very real. To the Machine, single tax was even more frightening than the initiative and referendum. It called for a minor restructuring of society, and a minor re-distribution of the wealth. This was too radical for the special interests. A campaign to defeat single tax was launched, and Oregon witnessed one of the greatest political duels ever to occur in the United States. 
1James H. Gilbert, "Single Tax Movement in Oregon," Political Science Quarterly, XXXI (March, 1916), p. 32.

20regon, Abstract of Votes, (Secretary of State, June, 1908).

${ }^{3}$ Robert C. Woodward, "W. S. U'Ren," Idaho Yesterdays, IV (Summer, 1960), p. 47.

"W. S. U'Ren, "Single Tax," Readjustments in Taxation, LVIII (March, 1915), pp. 225-26.

5Frank Parker Stockbridge, "The Single Taxers," Everybody's Magazine, April, 1912, pp. 505-25.

6A. N. Young, The Single Tax Movement in the United States (Princeton: Princeton University Press, 1916), p. 163.

${ }^{7}$ Stockbridge, "The Single Taxers," pp. 505-25.

8. G. Eggleston, A. D. Cridge, and W. S. U'Ren, People's Fower and Public Taxation (Portland, Oregon: Multnomah Printing Company, 1910), P. 14 .

9 Ibid.

$10_{\text {Ibid. }}$, pp. 16-17.

${ }^{11}$ Oregon City Courier (Oregon City, Oregon), February 18, 1910 , p. 4 .

${ }^{12}$ George H. Haynes, "People's Rule in Oregon," Political Science Quarter1y, XXVI (March, 1911), p. 34.

13 Oregon City Courier, May 13, 1910, p. 1 .

${ }^{14}$ Eggleston, Cridge, and U'Ren, People's Power and Public Taxation, pp. 122-23.

${ }^{15}$ Burton J. Hendrick, "Statement No. 1," McClure's Magazine, September, 1911, pp. 502-13.

16 oregon City Courier, July 22,1910, p. 6.

${ }^{17}$ Oregon Daily Journal (Portland, Oregon), August 12, 1910, p. 5. 
${ }^{18}$ Evening Telegram (Portland, Oregon), July 19, 1910, p. 2.

${ }^{19}$ Oregon Daily Journal, July 20,1910 , pp. 1-2.

${ }^{20}$ Hendrick, "Statement No. $1, "$ pp. 502-13.

${ }^{21}$ Oregon Daily Journa1, July 20, 1910, p. 1.

22 Ibid., August 11, 1910, p. 4.

${ }^{23}$ Oregon City Courier, August 5, 1910, p. 1.

24 Haynes, "People's Rule In Oregon," p. 34. 
CHAPTER IV

TAX AUTONOMY FRIGHTENS THE LEGISLATURE

I. VOTERS APPROVE "SECTION 1a."

U'Ren may have winced a little as he put into motion his 1910 tax proposal. The election year was overly complicated with governmental reform issues. The special interests clearly indicated a desire to destroy the whole Oregon System. This made the electorate very cautious and perhaps unwilling to do anything but preserve the existing arrangements. U'Ren's tax measure required voters to engage in considerable study and discussion in order to vote wisely on election day. Single taxers believed timing was critical. The special interests were feared, because they were gaining more control of Oregon's tax program. U'Ren knew voters realized something was wrong with the general tax laws, and he desired to capitalize on this.

In Oregon, and nationa11y as well, big business was fighting to retain power to regulate taxation and exemptions. The result was that fortunes were being spent to elect their men to the Senate. Special interests spent $\$ 500,000$ to elect Senator Simon Guggenheim of Colorado, and two and one half million dollars to elect Senator William Clark from Montana. U'Ren maintained the greatest motivation for these expenditures was related to tax regulation. He declared the right to regulate taxes belonged to all classes, to laborers, farmers, and corporation owners. But Oregon's single taxers believed the regulation 
of taxes was worth more to political bosses and big business than a11 other powers combined. U'Ren declared that this struggle over tax regulation began at the American Revolution and was still not settled.

The 1909 legislature sensed the pub1ic's concern about taxes and prepared two bills for their approval in 1910. Both bills were endorsed by the Oregon State Federation of Labor and the Portland Labor Counci1. One of the amendments was guided by the Grange through the legislature. It provided that no tax would be imposed without the consent of the people, while taxes would be coliected only for public purposes. The other amendment permitted voters to provide a law declaring what property could be taxed and exempted.

A third tax measure Oregonians were asked to consider was the one initiated by U'Ren and his supporters. Dr. W. G. Eggleston, a Portland physician from California, and A. D. Cridge, an Oregon City lawyer, helped U'Ren in planning the proposal. Single taxers supported the tax bills submitted by the legislature, as they gave valuable power to the people. U'Ren reasoned his tax bill was needed so that voters could effectively use the power. This was the closest cooperation U'Ren experienced with labor and the Grange. A unique combination went into U'Ren's strategy. Outward1y, labor, the Grange, and U'Ren were presenting to the public a united front. However, the Grange and labor did not have any desire for single tax, but U'Ren did. Later, U'Ren was accused of hiding his motives, but during the campaign his collaborators should have been aware of his plans.

The single taxer's measure was an amendment to Article IX of the State Constitution, designated as Section 1a, which read: 
No poll or head tax shall be levied or collected in Oregon, no bill regulating taxation or exemption throughout the state shall become a law until approved by the people of the state at a regular general election: None of the restrictions of the Constitution shall apply to measures approved by the people declaring what shall be subject to taxation or exemption and how it shall be taxed or exempted whether proposed by the Legislative Assembly or by Initiative petition: But the people of the several counties are hereby empowered and authorized to regulate taxation and exemptions within their several counties subject to any general law which may be hereafter enacted. 1

While the term single tax was not used in the proposal, special interests quickly saw it as a wedge for a 1912 single tax measure. The ingenius Section la permitting county control over tax systems was laying the ground work. U'Ren knew a state-wide single tax measure did not have a chance. But after the 1908 election, several counties looked promising. During the 1912 general election, U'Ren wanted to try a single tax bill in those areas. To present their position, the single taxers prepared a pamphlet, under U'Ren's direction, entitled People's Power and Public Taxation. Multnomah County, the state's main urban area, was considered a good prospect for single tax. In the pamphlet, U'Ren told the county's farmers, workers, and small businessmen, that Multnomah County would save nearly a million dollars every year by levying al1 public taxes on land values and franchise corporations, while abolishing all po11 and head taxes and taxes on improvements and personal property. U'Ren was concerned that Oregon's tax laws were based on the premise that men should pay taxes in proportion to the value of their property. General tax law advocates reasoned the citizen with more property received more government service and protection. To give the property owner exemptions would not permit him to pay his share. U'Ren complained general taxers were not holding to their own exemption 
philosophy. He declared exemptions were being given, but not in favor of the laborer and farmer. General tax laws could not be fairly levied, thus they bore most heavily and unjustly on the middle and lower income areas. These same areas were unable to control and evade the taxes as special interests were doing. 2

Single taxers believed the general taxers were controlling the flnancial destiny of Oregonians, with or without rea! estate, through inheritance tax, poll taxes, and other secluded taxes. These taxes kept most of the state's collection at the county level. Special interests wanted to keep the system, because their taxes were paid at the state leve1. Here, they could more easily control their illegal exemptions, while keeping the general public ignorant. Consequently, general taxers favored the two legislative bills because they maintained the greatest tax collection at the county level, and still within the grasp of their control. Government would still be largely supported by the personal property tax, inheritance tax, and poll taxes. With these laws, there would be no tax pressure at the state level, and franchises with big business would continue to benefit. With home rule over taxation, the public would eventually tap big business and franchises for their fair share of governmental support. This would be collection at the county level, and the only way special interests could control their taxation would be to control voting at the polls. Section la would put all the general tax laws within the people's reach, including personal property tax and the inheritance tax. In 1910, over four million dollars were collected from personal property and improvements. Occupation and po11 taxes 
brought the amount to five million dollars. U'Ren reminded laborers, farmers, and small businessmen that this amount was coming from them. Single taxers argued that Oregon would be the nation's leader if these types of discriminatory taxes were eliminated. They reasoned the land value, or single tax, was the logical replacement. U'Ren advised voters to carefully study the issue, not only Section 1a, but the greater prospect of single tax. This would put the pressure where the money was, on big business and franchises. He made it very clear that an affirmative vote for Section 1 a in 1910 would prepare the way for a distinct choice in 1912 between the general tax laws and single tax.

The electorate was carefully advised what single tax meant. Farmers were shown that an owner of a business lot in downtown Portland paid on a percentage basis less tax than the farmer. Based on the 1909 tax tables for Marion and Multnomah Counties, farmers were declared to have holdings in excess of thirty million dollars over thetr actual worth. The same tables revealed the speculators were being assessed four and a quarter million dollars below the value of their holdings. Inder single tax, farmers would not be taxed for cultivating new land, and speculators would be taxed more. Between 1907 and 1909, the assessment between farm land and speculative land became more and more disapportionate. Taxes on farm lands in Marion and Multnomah Counties increased by twenty seven percent. Taxes nn speculative lands decreased by more than five percent. In 1909 , farmers paid $\$ 502,675$ more in taxes in 1909 than in 1907. Speculators paid \$141,529 1ess in 1909 than in 1907. Single taxers calculated that famers paid one dollar 
and ninety-two cents under the general tax laws while they would have paid one dollar under single tax.

J'Ren charged that big business was willing to commit all manner of crime against the people to retain the power to control taxation and exemptions. As an example, on March 10, 1910, the We11s Fargo Company reported a profit unreasonably low in comparison with their investment. Many big companies reported low profits so the State Tax Commission could be persuaded to lower their taxes. Middle and lower income people were forced to pay the taxes big corporations did not pay. The rates that big business charged the people for use of their service were a particular source of irritation with U'Ren. Charges by big business were largely unregulated, especially the telephone, electrical, and local railroad companies. These rates paid for corporation taxes, attorneys to defeat the people's will in courts and legislatures, to pay for bribes to corrupt newspapers, to meet costs of political machines and bosses, and to pay a11 court costs in litigation between corporations and the people. The axom, "control of law making gives control of wealth distribution," greatly figured in U'Ren's economic philosophy.

Counter reformers contended Section la would result in confusion and double taxation. They reasoned citizens would evade taxes by moving from one county to another, but said nothing about their own evasions. Special interests feared for their power in the legislature. In their opinion, Section la prevented the legislature from meeting emergencies and from providing a comprehensive tax plan. ${ }^{4}$ U'Ren was accused of interfering with the State Tax Commission's work, while 
delaying what the legislature could do anyway. Critics rightly reasoned that when one county adopted single tax under Section la, others would be forced to follow. The Oregonian and the State Bar Association claimed that Section 1a was dangerous to property rights. When the annual state Grange meeting began discussions on Section 1a, time was short, and U'Ren motioned to table the issue, leaving the matter in the voter's hands. The motion passed, and the Grange did not enter into the controversy as in 1908 .

Critics later claimed the single taxers resorted to subtrefuge in presenting Section la by not openly describing its connection with single tax. Even out-of-state observers, such as A. M. Young believed the same thing. Nothing could be further from the truth. In U'Ren's pamphlet, speeches, and in the Oregon City Courier, a close follower of U'Ren's activities, the promise of a 1912 single tax measure was very clear.

Several observers believed U'Ren either had less trust in the justice of single tax, or a weaker confidence in the voter's inte1ligence. 5 They viewed Section $1 \mathrm{a}$ as the Trojan Horse of single tax. U'Ren was accused of stressing the poll tax section of the bill, while not emphasizing the county option phrase. The poll tax issue stimulated great controversy. State and national writers declared the 1907 legislature had eliminated all poll taxes. They reasoned Section la was a "bogie" to distract the voters' attention from the real issue. As will be described in another section, from all evidence, these criticisms were not true, and clearly misrepresented U'Ren's plans. In 1912, U'Ren's single tax measure and reconsideration of Section la was seriously handicapped by this unfair publicity. 
The results on the tax issues for the 1910 election were almost out of character with usual voting patterns on reform measures. Usually, those bills promoting the most radical tax measures had failed as in 1908. Yet in 1910, Section la passed. It is difficult to distinguish any voting pattern. All of the nonfarming counties passed it, but many farming counties also passed it. The margin victory for the measure was very sma11. State wide, the measure carried by no more than 2,000 votes. In spite of opposition to Section 1a by the Courier, which normally supported U'Ren, Clackamas County also favored the measure. The real surprise was defeat for the two tax measures submitted by the 1909 legislature and supported by special Interests, labor, the Grange, and U'Ren. A possible explanation, although not a very satisfactory one, is that special interests were more concerned with the other issues than with taxes. Also, Section 1a may have appeared to votars as saying the same thing as the legislative proposals.

After the election, U'Ren made public the amount of money spent by the Fels Foundation between 1909 and the election. Single taxers spent $\$ 16,775$ in Foundation money. Based on the Fund's operation, Oregon had to raise the same amount locally to get the matching dollars. Thus, U'Ren spent approximately $\$ 33,550$. There is disagreement over the exact amount of the budget.

The state was now closer to single tax than ever before. Still using Foundation money, U'Ren began planning single tax measures for the 1912 election in key counties. He predicted that at least six counties, including Multnomah, would accept single tax. 6 As he began 
an early campaign in Multnomah County, a strange combination fell in with U'Ren. Saloon keepers favored single tax because it removed their license fee, and ministers favored it because it would remove financial incentive from city and county councils to accept bribes permitting more saloons than necessary.7

As U'Ren and other single taxers looked forward to the battle in 1912, their private emotions were evident. One individual who listened to a speech by U'Ren wrote:

I wish I could put on paper something of the thrill of prophecy in W. S. U'Ren's voice as he said, "When Oregon says to the rest of the United States, you can bring your money and your stock and your goods to Oregon and we won't tax you for it, then all other states will have to follow, and they will do it faster than they are coming to the initiative and referendum." 8

Another writer quoted a single taxer as saying, "The single tax stands for democracy, and I stand for the right of each generation to make its own mistakes."

If laborers, farmers, and small businessmen understood the devotion in which the memory of Henry George was he1d by his "disciples," they would know there was something enduring, something spiritual, something far removed from the:

sordid and material that inspires these soldiers of the Common Good. It is the spirit of unselfishness that prevades and levens the whole great forward movement of democracy as we are seeing it in America today, that underlies and dominates the great upheaval which is expressing itself in the demand for popular government and which finds so much of the inspiration in the teachings of Henry George. 9

U'Ren was a self-imposed "soldier of the Common Good." He devoted all his time and most of his personal money to the effort. To do this, he denied himself wealth and a comfortable law practice. One of U'Ren's 
enemies was taken by his devotion, and in commenting on the passage of Section la said, "It has been one of the smartest pieces of politica1 work in the United States of which we have a record."10

As the impending battle loomed, U'Ren received some reinforcenent from Henry George, Jr., son of the famous economist, who was visiting and speaking in the West. Early in January, 1911, he was in Vancouver B. C. reviewing their progress with single tax. On Saturday night, March 18, 1911, he spoke in Oregon City at Willamette Ha11. He told his audience that he favored one tax for all purposes on the 1 and, not industry. Present taxes, he said, were a penalty on hard work and a protection for monopoly. 11 He predicted the old system would break up nationally, while popular government took over. George Jr. foresaw the nation following Oregon's lead in reform, but including single tax which promoted free trade. He described land monopoly as the greatest and most dangerous kind. There cannot be a monopoly of air, he said, but there was one of land. The two could not be separated. George Jr. complained that men spoke of the land as theirs but quickly added that he did not want the government to divide up the land between al1 the citizens. He implied this was impossible, because some land was nore valuable than other 1and. The overriding concern of George Jr. was to enact laws permitting every man and woman to develop within their capacity without interference from political bosses and big business. Joseph Fels also toured and crossed paths with Henry George, Jr. Fels was accompanied by David Keifer of Cincinnati and R. L. Scott of Winnipeg, Canada. The trio toured the country preaching the "gospe1 of the single tax."12 They implied governments a11 over the world were 
rapidly approaching the millennium in the struggle for equal opportunity. While in Oregon City during January, 1911, they conferred with U'Ren over Oregon's 1912 single tax campaign. Fels was delighted over passage of Section $1 \mathrm{a}$, and probably had a hand in deciding which counties single tax measures would be fought for. Before Fels' visit, $U^{\prime}$ Ren envisioned a fight in most of the counties, but after Fels left, the number was greatly reduced. Perhaps Fels, being from out-of state and as a major supplier of funds, saw implications in a wider fight that U'Ren did not see.

II. THE 1911 LEGISLATURE PREPARES FOR THE SINGLE TAX TEST

When the 1911 legislature gathered in January, Governor West appealed for modification of Section la. He wanted the county option phrase to be removed, while retaining the poll tax clause. Realizing something had to be given in order to get his wish, Governor West suggested the legislature give up its emergency appropriation clause. The legislature dearly loved its emergency powers, but was frightened by the county option. 13 At first, the legislature was slow in moving, because voters were already angry over its inability to pull together tax reform and prevent the raising of taxes.14 However, the state Tax Commission made a comprehensive report to the legislature suggesting strategy. This forced the legislature into action.

The Tax Commission had a short history, but it put perspective to decisions made by the 1911 legislature. Since 1905, Oregon's legislature had attempted to do something about taxes. In 1905, the legislature thought it was responding to the public's demands for 
reform by passing legislation setting up a Tax Commission to examine the laws, and to make recommendations. The Commission consisted of the governor and selected citizens. While the Commission was supposed to be impartial, reformers uncovered evidence that franchise corporations and big businesses, such as the Wells Fargo Bank, actually controlled the Commission's decisions. The first report of the Commission was published in July of 1906, while F. W. Mulkey was chatman. This report reveals evidence of early concern over the pol1 taxes. A careful review of the action between 1906 and 1910, further reveals there was a poll tax on the books when Section la was approved by the voters.

The 1906 report revealed that Oregon's county assessors had twice suggested since 1900 that poll taxes be abolished. The state had two types of pol1 taxes. One was a state poll tax of one dollar, and the second was a road poll tax of three dollars. Each tax was collected on a yearly basis from males over twenty-one years of age. The state poll tax was collected on the state level, and the road poll tax was collected on the county level for maintenance of roads and bridges. It was the assessor's suggestion that if poll taxes were not to be completely abolished, then the state poll tax should be dropped and added to the road poll tax, making it a four dollar per year tax. The Commission agreed with the suggested four dollar road poll tax, because the state po11 tax was a "dead letter."15 The report noted there were not any means to enforce the state poll tax, and as a practice, it was only charged against those paying property tax, whereas all males were subject to it. They estimated that only one-tenth of those who should 
have paid the state poll tax did so. Thus, the Commission recomnended new legislation for the 1907 session. The suggestion was to remove the state poll tax and require every male between twenty-one and fifty to pay a road poll tax of four dollars, to be collected by the road supervisor in the appropriate district. 16

In accordance with the Commission's suggestion, the 1907 legis1ature repealed the state poll tax of one dollar. However, the legislature did not add the one dollar state poll tax to the three dollar road poll tax, as the Commission desired. Therefore, the road poll tax of three dollars was still on the books after the close of the 1907 session, and the 1909 session did not discuss the matter.

When the publication of Oregon's statutes changed from Cotton and Ballinger to Lord's Oregon Laws, the section referring to the poll tax was worded the same. Lord's Oregon Laws uses the phrase, "road or pol1 taxes." A case argued in the Oregon Supreme Court further documents the presence of the road poll tax in 1910, when Section la was passed. On December 1913, the Court heard a case concerning an accident in Sheridan. A traveler was injured on the town's bridge and was suing for damages. The Court criticized Sheridan for not using the road poll tax it had collected to repair the bridge approach, and the traveler won the case. 17

The first biennial report of the State Tax Commission was given to the 1911 legislature. In the report, U'Ren's Section la was seriously criticized. The Commission complained the ballot was under an attractive title and not understood. In keeping with the special interest's desire to remove power from minorities, the Commission objected to the measure being passed by less than a majority of the voters. 
In the biennial report, the Commission told the legislature that with regard to the poll tax, Section la was of little consequence because the "po11 tax was repealed by statue in 1907."18 Yet, as has been shown, in 1910 the road poll tax did exist. The Commission deliberately did not refer to the road poll tax. It is a mystery why the road poll tax section 6326 was not deleted from Lord's Oregon Laws after Section la was passed in 1910. The tax remained on the books, and was operative, but illegal. This condition remained until the 1913 legislature made the necessary corrections.

Lofty objections were raised by the Commission to the county option in Section la. The report said it deprived the legislature of any right to enact tax laws. Independent county systems were considered a danger. U'Ren planned to meet this objection by specifying that a county had to raise as much tax as before single tax was adopted. To the Comission, local option appeared contrary to the need for general tax reform. They wanted centralization of authority and uniformity of laws. The report presented a series of quotes revealing single tax could only come in gradual steps as in Section 1a, thus, making the legislature most anxious to work for its destruction.

The report admitted that Oregon's general tax laws were in disarray and criticized the 1909 legislature's use of the emergency clause to equalize revenue between counties. For corrective measures, the Comnission supported Covernor West's proposal, while urging a bill to be submitted in 1912 giving the legislature power to make tax laws. Because the Commission viewed Section 1 a as a serious threat, they recormended that a special comnitiee be established by legislative resolution to coordinate a11 efforts for the 1912 election campaign. 
On February 7, U'Ren found he did not have one supporter in the legislature for his tax proposals. Without a dissenting vote, the resolution for the repeal of Section $1 \mathrm{a}$ and the other Commission recommendations passed both the Senate and House. The campions for the repeal of Section la were two former supporters of U'Ren. They were Senators W. A. Dimick, a brother of Judge Grant Dimick, and Claude C. McCullock, the strongest advocate of the Oregon System in the 1911 legislature. Dimick called the single tax a political fraud and denounced Fels with "bitter invectives."19 McCu1lock took the floor and declared the single tax and county option amendment would result in a hodgepodge of tax assessment. He said it was time to get the Oregon System out of the hands of radicals who were perverting its use.

Dimick took the floor again, charging that Section 1a was passed by fraud, deceit and intrigue. He said catchy phrases, such as "more power," glossed over the "evil of evils," the single tax. Dimick asserted he was a friend of the Oregon System, but was against perpetuating fraud to secure single tax. He charged that U'Ren and others were socialists, anarchists, and soapbox orators. He declared single taxers advocated "to he11 with the government."20 But he a1so acknow1edged that single taxers were honest people. The senator accused big business of backing Oregon's single tax movement. In his conclusion, Dimick said that once all the wealthy industries had been exempted by single tax, the farmer, "a grubber of the soil," and the small home owner would pay all the tax. To U'Ren, these were dangerous words, and precluded a bitter fight in 1912. They also demonstrated that time was short for continued reform. 
Dimick's conclusion was opposite of the facts. First, with the Oregon System and single tax, the people, not industry, would decide who was and who was not exempted. Secondly, U'Ren was designing a single tax measure insuring that farmers and laborers would not pay an unfair rate of tax. He made this very clear in the pamphlet, People's Power and Public Taxation. Dimick and McCullock had every opportunity to read and study this work. The logic of these senators was a preview of the propaganda special interests would use during 1912. The similarity suggests that Salem was filled with clever lawyers from the special interests attempting to influence the legislators.

Following the State Tax Commission's suggestion, the legislature set up a joint committee of twelve legislators charged with preparation of tax measures for submission to the people in 1912. They were to prepare arguments against all other tax proposals. The five senators and seven representatives on the legislative committee were to work with the Tax Commission. 21 The Secretary of State was designated to furnish the committee with all the needed material. Before the session closed, the legislative committee said single tax was acceptable under an amended Constitution, but only by a vote of the entire state, and not by a county vote. While this was contrary to Section la, U'Ren took notice, and it may have influenced a surprise move in 1912 . Thus, when the 1911 legislature closed, they had referred severa1 tax bills to the people designed to meet public demand. Certain personal items would be exempt, proposed changes in the inheritance tax rates were made, the income tax was proposed, and taxes on debts would be abolished. The bill repealing the county option clause of 
Section $1 a$, and repealing the emergency clause, while retaining the section prohibiting poll tax was also submitted. Another bill for the voer's consideration, declared that taxes could be used only for public projects, and the legislative tax power would never be suspended or surrendered.

U'Ren and the other single taxers clearly understood their position. While Section la was a gain, the ponderous forces of the special interests were grouped to defeat it. Counter reformers had no intention to let the campaign be a quiet one in which the voter could reflect on the merits of just the single tax. The Republican Machine and big business were prepared to reach unusual lengths in their effort to suppress the single tax movement. Money, 1ies, and exaggeration would be used. U'Ren would rest his case on efforts to make the truth widely and easily available. He would stress his morality, and continually report the sources of his support. Total effort was needed by the single taxers to insure gains and prevent setbacks. 
IW. G. Eggleston, A. D. Cridge, and W. S. U'Ren, People's Power and Public Taxation (Portland, Oregon: Multnomah Printing Company, 1910), p. 26.

${ }^{2}$ Ibid., pp. 27-28.

$3^{3 \text { Ibid. , p. } 98 .}$

4James H. Gilbert, "Single Tax Movement in Oregon," Political Science Quarterly, XXXI (March, 1916), p. 6.

5F. G. Young, "Public Finance," American Economic Review I (November, 1911), p. 643.

6rank Parker Stockbridge, "The Single Taxers," Everybody's Magazine, Apri1 1912, pp. 505-25.

7 Ibid., pp. 505-25.

8 Ibid.

9 Ibid.

10Charles H. Shields, Single Tax Exposed (Portland, Oregon: Oregon Equa1 Taxation League, 1912), p. 16.

${ }^{11}$ Oregon City Courier (Oregon City, Oregon), March 24, 1911, p. 1. ${ }^{12}$ Ibid., February 3, 1911, p. 1.

${ }^{13}$ Oregonian (Fortland, Oregon), February 20, 1955, p. 12.

14 Young, "Public Finance," p. 646.

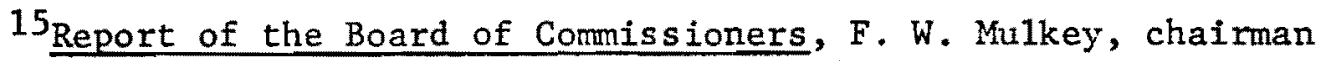
(Salem, Oregon: State Printer, 1906), pp. 82-3.

16 Ibid., pp. 180-81.

${ }^{17}$ Reports of the Supreme Court of Oregon Vo1. 68, F. A. Turner, reporter (San Francisco: Bancroft, Whitney, Co., 1914), p. 239.

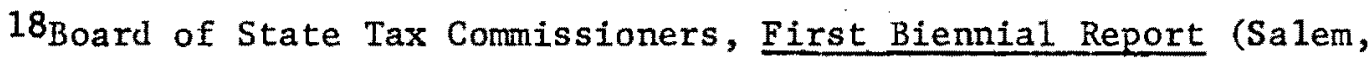
Oregon: State Printer, 1911), p. 22. 
${ }^{19}$ Oregon City Courier, February 10, 1.911, p. 1.

20 Ibid.

21Young, "Public Finance," p. 648. 


\section{CHAPTER V}

\section{THE 1912 SINGLE TAX DEBATED IN LETTERS AND PAMPHLET'S}

\section{THE ISSUE}

It was not until early 1912, that U'Ren announced the actual single tax campaign areas. Only Multnomah, Clackamas, and Coos Counties were selected. Multnomah was selected because of its urban setting and large laboring class. Wage earners were considered potential supporters of single tax. Clackamas, U'Ren's home county, was chosen for the same reason and because the county's farmers were thought intelligent. The presence of the Oregon City Courier was another favorable factor. Coos County was dominated by timer interests which controlled the 1and. Citizens of Coos County were concerned and had shown strong support for single tax measures.

When the single tax measures for the three counties were published, they did not come as a surprise to the voters. The three measures were very similar, and the one for Clackamas County is quoted:

Section 1: That a11 business, labor, trades, occupations, professions, and the right to conduct work at or practice the same; and al.1 forms of personal property; and all improvements on, in, and under all lands shall be and hereby are exempted from taxution for any purpose in Clackamas County, and no tax sha 11 be imposed upon any trade, labor, business, person, occupation or profession under the profit of a license or the exercise of police power within said county; but in its application to licenses and permits and to prevent exacting fees therefore greater than the cost of issuing the permit or license, and is not intended to impair the police power of the county, city, or state. 
Section 2: A11 taxes within Clackamas County sha11 be levied on and collected from the assessed values of a11 lands, water power, deposits, natural growths, and other natural resources, and on and from the assessed values of public service corporations, franchises, and rights of way. This act does not affect corporation license fess and inheritance taxes collected directly by the state, nor such lands as are used only for municipa1, educationa1, literary, scientific, religious or charitable purposes, a1 ready exempt from taxation by 1 aw.

This relatively simple proposal brought to Oregon a unique campaign. Extremes in accusations and emotions were demonstrated. Counter reformers called single taxers communists, while single taxers labeled the special interests as criminals without conscience. The average citizen expressed greater concern in the single tax issue than in most reform measures.

II. THE OREGON CITY COURIER PROMOTES SINGLE TAX DISCUSS ION

One of the greatest liabilities of U'Ren's reform movement was the unfavorable press. As already demonstrated, many of Oregon's newspapers were controlled by the Republican Machine and its big business supporters. The Polk County Observer complained that too many Oregon editors had "garden hoses" for back bones, while others were "silenced" by a "three inch advertisement contract." One editor commented that no more than six Oregon editors stood for anything, or dared to comment and criticize.1 The state's papers were repeatedly styled as "weaklings and nonentities and absolutely void of strength, character, force or interest." 2

During the 1912 campaign, the influential Courier took a strong stand for single tax. This was a departure because even though $U^{\prime} \operatorname{Ren}$ had always been favored, the paper opposed the 1908 single tax measure 
and Section la in 1910. While there is no documentation, it is likely that U'Ren had a hand in persuading the change because he was desperate for support by a major paper. On July 28, 1911, the Courier announced a policy of printing a11 letters for and against single tax. The announcement said Oregon needed much education on the matter. The policy continued up to the 1912 election. This was in keeping with U'Ren's style, and it gave him the opportunity to directly answer voter's questions in writing.

The Courier quickly became the state's newspaper spokesman for single tax. Shortly after the announcement, a new editor from the East came to the paper. He was M. J. Brown from New York state. There he edited a small town paper known as the Little Valley Hub and was noted for his political activities. 3 It is uncanny how upon arrival in Oregon City he immediately announced his support for single tax and U'Ren. It is curious how he could be so familiar with the issue and $\mathrm{U}^{\prime}$ Ren to support them in so short of a time.

It was not long until voters were writing to the Courier expressing their views on single tax. In one of the first letters, a farmer complained he had little to leave his children, but would have nothing to leave them under single tax. He said this was true because he would be paying taxes for business and professional people. U'Ren's answer was printed on the first page of the next issue. 4 He asked the farmer if he would be hurt by not paying tax on the value of cleared land and buildings. Continuing, he asked if the farmer would be injured if the Southern Pacific Railroad had to pay the same tax for keeping their land idle that he paid for clearing and using the land. U'Ren noted 
that with single tax, the famer would pay taxes on just the land at ninety mills rather than twenty to pay his same tax of forty-six dollars. To charge the Southern Pacific ninety mills would force them to "look lively for buyers."

U'Ren worked a moral issue into his answer: "But has our friend thought of the morals in this tax question?" He wondered who made the land worth seven dollars an acre. It was not the speculator, he concluded, who did not develop the ground. U'Ren reminded the famer it was he who made the land valuable. The more land he and new farmers cleared, the better schools and roads they could build and the more valuable their land would become. U'Ren asked:

If the presence of all the people makes the land valuable, would it be morally wrong to collect all the taxes and pay community expenses of govermment out of that land value created by all the people?

He warned the farmer to take nothing for granted and asked that he carefully study the sing.e tax question. U'Ren suggested the single tax on land values was either right or wrong, and that it would pay the farmer to find out.

This particular farmer could not understand the moral aspects that U'Ren suggested. He simply did not grasp how dead land could be taxed at the same rate as cleared farm land. Neither did he understand that the speculator's profits came from the presence of people, and not from something the speculator did to the land. In frustration, the farmer replied to U'Ren saying he could not understand how anyone of U'Ren's callbre could get mixed up with single tax. The farmer reasoned that a certain amount was needed to run the government. To remove "more 
than half" of the county's wealth from taxation, and put it on land was a "hocus pocus" he refused to comprehend.

U'Ren continued to raise the moral issue. In replying to another farmer, he asked if it was morally right to have a law under which men could earn $\$ 40,000$ or forty cents without any labor. Speculators were earning a good deal of money without working. The farmers were paying taxes on land and improvements, while some were paying a high rent to the land owner. In contrast, the speculator was paying very little in taxes. For an example, U'Ren used the Oregon and California Railroad. This corporation was holding land for profit. For every five and one half acres they held, the corporation was only paying as much tax as the farmer paid on one acre. U'Ren concluded his reply by saying he had never heard of farmers making European tours or buying expensive automobiles from the profits of his labor. 5

The letters raised questions about the single tax confiscating a11 land and exempting manufacturing. In his answers, U'Ren made a distinction between Henry George's plan, and the version to be presented in the three selected counties. George's system collected the tax from the total rental value of the land. The Clackamas County single tax would tax only a partial value of the land, but would also tax public service corporations. Under these terms, confiscation was impossible. The Oregon System would also prevent such a drastic measure because the people would not allow it.

Manufacturing was exempted, U'Ren said, because the plant owner did work. Some farmers contended the owners did not and classified them with speculators. The manufacturer kept. money in circulation, 
while speculators engaged in a one-way flow. U'Ren reiterated it was morally wrong for one to get the product of labor from other without giving equal value in return. He continued:

In the sweat of thy face shalt thou eat bread, and He that will not work shall not eat." This I believe is the divine moral law of labor. My ideas of morals may be old fashioned, but some other good men have believed the same way. 6

U'Ren concluded that speculators wrong the whole community, as they did not pay their share of taxes to support schools and good roads.

In a letter by 0 . D. Robbins, a Clackamas County farmer, issue was taken with other letters that claimed Joseph Fels wanted single tax in Oregon so he could bring in his soap plants and take over the state. Robbins believed the general tax laws encouraged hoarding and discouraged manufacturing. Manufacturing paid its way in part through single tax by being taxed on the valuable land it occupied. He favored the single tax position that loaned money would not be taxed. Money, he said, was evidence of work. When loaned to a busiress or for improvements, the whole community benefited. Robbins declared "let Fels come to Oregon, and bring others with him."7

One writer was fearful of what would happen after all the speculators sold their land due to higher taxes and left the state with their "millions." He wondered who would then pay the taxes. Editor Brown replied that Oregon did not need the speculators, but people who would buy their land and develop it. The people would increase everyone's investment. The rich man could invest in Wall street or throw his money in the Willamette river, and the community would still get double the taxes without him. Oregon was a "gold mine," but no one could dig because so little was settled. Eastern millionaires were 
seeing to that, Brown charged, by tying up land as a financial investment for their sons twenty-five years in the future. 8

G. B. Dimick, now the mayor of Oregon City, wrote a letter in the Enterprise which stimulated several responses in the Courier. Dimick claimed single tax would not tax water power or railroads, while injuring all industry. Eggleston was one who answered, charging that Dimick was deceived by the "wild Oregonian." Eggleston demonstrated how water power and the railroads would be taxed. This was one element that many farmers would not believe. Dimick was challenged to show how industry would be hurt. The single taxers did not want to offend anyone, Eggleston concluded, only to prove the comnon people were "scapegoats for taxation." 9

Charles $\mathrm{H}$. Hartman also responded to Dimick. Hartman was known in Oregon for his essays on science and economics. The base of his defense for single tax was a quotation of Moses, "Moreover, the profit of the earth is for all." Philosophers, he said, believed that whatever was taxed was destroyed. A tax on land could not destroy it, thus it was a progressive, not a regressive tax. Land speculation had been a curse for centuries and needed to be destroyed. Single tax restored to man his natural inheritance. Hartman compared Oregon's general tax laws to Babylonian 1aw, and single tax to the Mosaic law. "The land shall not be sold forever and moreover, the profit of the earth is for a11. $" 10$

The Courier letters reveal a good deal of concern over how new farmers would fare under single tax. Two farmers, E. Cox and o. Horton, contributed a joint letter addressed to this concern and described single tax as an issue between city people and farmers. They were 
convinced that city people were natural single tax supporters. A beginning farmer would not be as well off as a city dweller. Under single tax, the new farmer would pay more than through the general tax laws. Even though his tax would not raise as improvements were made, Cox and Horton were against it. It was their opinion that single tax would lower land values, allowing capital to move in and buy up all the land. A huge profit would result when land resumed its true value. They concluded, "those that love the old flag and country won't tolerate a ruinous experiment." 11

As the campaign advanced into 1912, U'Ren answered fewer letters because of a busier schedule, while editor Brown took on more of the responsibility.. He reminded $\operatorname{Cox}$ and Horton that land value in the cities was two-thirds greater than farm land. He reasoned that single tax would assure famers of only paying a third of the taxes. Brown commented how strange it was that famers were fighting for the privilege of paying taxes the speculators should be paying.

A. J. Keinhofer, another farmer, wrote several letters that created anger among the single taxers. He was accused of signing letters written by a lawyer representing big business. Keinhofer accused U'Ren of double talk. In 1910, he claimed U'Ren said industry would pay less with single tax, and now was saying farmers would pay less. This was a clever charge, because both industry and farmers would save. U'Ren was making this point clear from 1908 right up to the 1912 election. Keinhofer, or the lawyer, was saying the single tax transferred taxation from one class to another, while excluding speculators and franchise corporations. 12 
Both Eggleston and Brown struck back at Keinhofer. Of the two, Brown produced the most colorful remarks. Brown believed Oregon was about to revolt against high taxes. He labeled Keinhofer's charge of U'Ren double-talking as "more like tomato mash than brains."13 Keinhofer, he said, was simplifying the issue into a revival meeting or a "mother's meeting." Eggleston tried to discredit Keinhofer by accusing him of not paying his taxes. This charge came after Eggleston had carefully set out the facts about single tax, which Keinhofer passed off as nonsense.

The majority of letters were opposed to single tax. Even so, the Courier carefully printed them, giving single taxers the chance to explain their position. Their answers were as precise and polite as possible. However, as the November election drew near, they became less patient with the voter's stubborness to understand. Single taxers were accused of hiding something more fearful behind the single tax. Farmers were opposed, and nothing would change their minds, Oregon farmers believed that too long they had been victims of schemes to cheat them from their profits. In 1912, they were determined not to be taken again. The Oregon System gave them authority, and they intended to use 1t. Counter reformers were quick to recognize their attitudes and played on their fears. Farmers prided themselves in being realistic and experimenting was not realistic, even on a small scale in one or three counties. They did not recognize the practicality of U'Ren's idea1ism. 


\section{PAMPHLETS EXPRESS THE 1912 \\ SINGLE TAX ISSUES}

More pamphlets were used in 1912 than perhaps any previous election year. Most of them dealt with single tax. Thousands of copies were in circulation, and some observers described the election in 1912 as the pamphlet war. The single tax issue was intensely fought and it closed down around thepeople. At best, tax structure was a complicated thing, creating a need for clear, and understandable facts. This was the attempt of both sides: To present clear and convincing arguments.

The policy of the Oregon City Courier to print letters expressing al1 views of single tax produced the campaign's most remarkable pamphlet. A writer who simply signed his letter F. M. shared his preceptive analysis. No one, he observed, had changed his mind about single tax In spite of al1 the open discussion. He was troubled and really wanted to know what taxes would look like if single tax was adopted. Therefore, he challenged single taxers to go over the assessment rolls of Clackamas County and produce a dummy assessment of the way the roll would stand with single tax. 14

Six weeks later, on December 1, 1911, Brown announced that single taxers had accepted the challenge to produce dummy assessment rolls. This turned out to be a huge task, and it was not until the middle of July, 1912, that the pamphlet was published and distributed. of al1 the pamphlets, this represented the most exhausting research. After it was published, the opposition felt compelled to quickly issue more pamphlets than they had printed before it appeared. It was issued at a timely point, when the opposition to single tax was accumulating many positive reactions. 
The pamphlet was entitled Clackamas County Assessments and Taxes in 1910. U'Ren and Eggleston were the principal writers. In their review of the tax rolls, they were aided by the deputy assessor of Clackamas County. In addition to a large explanation devoted to the campaign and single tax, thirteen hundred entries were printed. These entries showed what the tax payer paid the county in 1910 on their property, and beside that figure, appeared what they would have paid with single tax. The single tax figure was always a few dollars less than the actual tax. As the dummy rolls did not represent any more tax than was actually collected, the difference in the sma11 land owner's tax was paid by public service corporations, franchises, and speculators. After it was published, its accuracy was apparent, but there was a complaint that it contained four mistakes. U'Ren said considering the mistakes made by the State Tax Commission, his effort had proven itse1f.

The first thing accomplished in the pamphlet was once again to show the difference between Henry George's single tax and the Clackamas County propose1. This was an attempt to dispel the fear that eventually single tax would confiscate all the land. Single taxers did not have any intentions of collecting taxes at one hundred percent of land va lues.

One of the first references to Charles H. Shields is found in Assessments and Taxes. He was the secretary of the Oregon Anti-Single Tax League. Until its exposure, the League was quietly working in the state. One of their chief arguments was the Section 1a was passed under fraud. Shields was claiming that the bill's title was "A Bil1 to 
Abolish Poll Tax."15 U'Ren said there was not such a bill on the 1910 ballot. The actual title was, "For A Constitutional Amendment providing for the people of each county to regulate taxation and exemptions within the county regardless of constitutional restrictions or state statutes and abolishing po11 or head tax."16

U'Ren explained the existence of the road poll tax, and presented evidence that it was collected in 1910. Letters were sent to county clerks by the single taxers inquiring about the collections. The clerks who answered confirmed the po11 tax had been collected. The Linn County clerk wrote, "every road district collected a three dollar road poll tax for the past several years up to and including 1910."17 The Oregonian was charged as the opposition's leader in the pol1 tax issue. U'Ren further charged the State Tax Commission with helping the Oregonian in fabricating the stories. The paper declared the tax was not collected, and persuaded such organizations as the Portland Realty Board to endorse the misconception.

After dealing with the opposition's propaganda items, the pamphlet presented a detailed discussion of the general tax laws. These laws perpetrated of many injustices. An example was a lot on the corner of Seventh and Morrison Streets in downtown Portland. The lot contained 5,000 square feet, or less than one-eighth of an acre. The 1910 assessments showed the land was worth $\$ 105,000$, improvements worth $\$ 5,000$, with a total of $\$ 110,100$. The city lot was leased on December $3 i$, 1910, to the Morrison Trust Company for fifty years with several conditions. The lessee paid a11 taxes and assessments on the land plus taxes on the building to be erected. The ground rent had to be paid by 
the lessee at the rate of $\$ 13,500$ per year for the first ten years. During the fifth ten-year set, the rate was $\$ 24,000$ per year. The overal1 average payment per year was $\$ 19,000$ dollars, or sixty-four dollars per day.

"Farmers!" demanded U'Ren, "measure off your yard in a fifty by one hundred foot plot," the size of the Portland lot. The monthly payment on the lot was $\$ 1,125$ per month, for only the raw land. U'Ren declared there was not a single tract in Clackamas County, of five hundred acres in farm land that would yield $\$ 1,125$ per month. U'Ren's point was the speculator owning the lot, paid a smaller percentage of taxes than the farmer.

The electrical companies and the State Tax Commission were charged with fraud. Assessments and Taxation did not include a tax entry for the electrical companies because the Commission refused to tax them. The Commission claimed there was not a law permitting such taxation. Electricity worth $\$ 8,076,707$ was sold in Oregon City alone in 1910 . Single taxers thought it strange the Commission would ask the legislature for repeal of Section $1 \mathrm{a}$, and not for laws permitting electrical companies to be taxed. If just the Oregon City company had been taxed, the general levy would have been eleven mills rather than fifteen mills. The single tax millage for the dumny rolls would have been fifteen mills rather than twenty-three mills. Farmers would have paid an average of seven dollars and sixty cents less under the general tax laws if these companies were taxed. U'Ren pleaded, "don't you understand now why the State Tax Commission and the Water Power (electrical) trusts are so opposed to the Clackamas County Tax and Exemption Bil1?"18 
Farmers were told by special interests the corporations would not be taxed, while city buildings and lots would be almost completely exempted. This, the opposition claimed, left farmers paying all the tax. As the pamphlet carefully revealed, the assertion was just that. Counter reformers were quoted:

See how these single taxers would exempt the big merchants and put extra taxes on you farmers. Take the 01ds, Wortman and King store in Portland, with $\$ 499,000$ worth of building and goods. Almost half a million dollars that the single taxers would exempt for one store. 19

The farmers should have realized that to exempt the building meant lower prices, but such statements frightened them. As it was, the business passed to customers the tax in the purchase price. The result was that business did not pay taxes.

To further clarify single tax, U'Ren presented in addition to the regular tax entries, several detailed charts. One chart described taxation for C. E. Spence's farm, the Grand Master of the State Grange. It appeared as follows:

C. E. Spence's General Froperty Tax Account for 1910--Tax Rate, 15 Mills

Director labor value in 30 acres.

Assessments

Taxes

(Value of labor in cultivating

30 acres) ..................... 750.00

$\$ 11.21$

Director labor value on 1 and. (Assessment of improvements, livestock, and personal property)........................ 1050.00

Assessments on labor................ 1800.00

Taxes on labor..................... 27.00

Raw-1and value of 70 acres

(30 cultivated, 40 raw).............. 1400.00 21.00

Total assessments and taxes.......... $3200.00 \quad 48.00$ 
C. E. Spence's Raw Land Value, Single Tax Account for 1910--Tax Rate, 23.18 Mills

$\begin{array}{ll}\text { Direct labor value in land............... Exempt } & \begin{array}{l}\text { Taxes } \\ \text { No Tax }\end{array} \\ \text { Direct Labor value on 1and } \ldots \ldots \ldots \ldots \ldots . . . \text { Exempt } & \text { No Tax }\end{array}$

Community made or raw land

value of 70 acres..................\$1400.00 $\$ 32.45$

C. E. Spence's savings of fifteen dollars and fifty-five cents

was common for most of the tax entries. This tax would remain constant regardless of improvements or additional land put under cultivation. If voters realized additional needs for schools and roads, an election would determine if the tax rate would be raised. It is important to remember the single tax rate of 23.18 mills raised only the amount of revenue, on a county-wide basis, as collected by the general tax laws.

Spence's reduction in taxes provided by single tax was compensated for, as already explained, by applying the same rate to land speculators. Following is a chart revealing the additional taxes to be paid by the seven largest speculators in Clackamas County:20
Taxes in 1910
Oregon and California land grant.....\$22,971.85
Weyerhauser Land Company........... 3,323.49
T. D. \& S. E. Collins............. 8, 898.74
Oregon Iron \& Steel Company.......... 3,777.72
Union Lumber Company.............. 964.60
Mola1la Land Company.............. 1,799.94
w. R. Burt.................... $\frac{857.02}{\$ 41,993.96}$
Increase by Clackamas County
Single Tax.
$\$ 18,440,90$
Opponents of single tax were afraid of the incisive arguments and facts presented in Assessments and Taxation and other printed materia1. It seemed reasonable that with a little study, the average farmer could understand the arguments favoring single tax. U'Ren primarily directed 
all of his material to famers because the destiny of his tax reforms was in their hands. Consequently, counter reformers also directed their main thrust to the farmers. The Oregon Anti-Single Tax League, and other efforts could not deal with facts or the truth. Reasonably, the side presenting the truth would have an edge. However, in 1912 , farmers found the facts difficult to believe. Perhaps the facts pointed out so much corruption that they could not comprehend it.

Under the auspices of the Oregon Anti-Single Tax League, Charles Shields a1so published many pamphlets. His most complete and able was Single Tax Exposed. He largely dea1t with Henry George's Progress and Poverty. Completely ignoring the moral issue in George's book, Shields exaggerated and. claimed land tax would deliver all property to the government. Shields maintained land value tax was too great of a burden. Single Tax Exposed claimed that single taxers believed crime would end when private property was abolished. 21 The author declared single tax was only alive because Fels made it his religion. A11 scientists and economists, he said, believed single tax was impractical. Farmers were told single tax would remove all rental value from the land. This would lead to destruction of the foundation business rested on. Shields said he feared the "end of our present social and fiscal system." Single tax was not considered tax reform or even a system of taxation. It simply meant confiscation and robbery. Because of this, no incentive would be left for making public improvements. Single tax was compared with communism, although Shields admitted single taxers disliked the term. 
Shields believed that people had different levels of intelligence. People who wanted huge land holdings should be allowed to have them, regardless of the effects. He did not agree that government should protect minorities and allow men of all intelligence levels to develop to their capacity. To Shields, it was not fair to hold back an agressive man simply because a less able man should have the same opportunity. Survival of the fittest and Herbert Spencer's ideas were popular in that day and in his arguments Shields used both. Because the animal kingdom functioned on survival of the fittest, Shields believed human beings lived the same way. Sympathy for the less fortunate was scorned. He wrote, "we must not however, allow emotion and sympathy to distort and warp our judgment."22

Shields admitted that a farmer who paid two hundred dollars under the general property tax laws might pay one hundred seventy-five dollars with single tax. The difference, reasoned Shields, was so slight that the tax was still there, only shifted. He did not say where it was shifted. He could not admit single tax shifted more of the burden to big business, because his propaganda scheme would be ruined. Special interests wanted the voters to sympathize with them, their low profits and their need for high rates. The author did not mention the farmer's tax would remain constant as he cultivated more land, planted bigger crops, and controlled more dollars. The Courier letters implied taxes prevented famers from developing, and big business did not want wealthier farmers to take more dollars out of circulation. Shields and special interests were overlooking the fact that allowing more land development and lower prices would create more demand. 
The single tax experiment in Vancouver, B. C., was largely surpressed in Oregon's press. But word did spread, and many Portland workers left their families in Portland and traveled to Vancouver to work for the higher wages. The city was the fastest growing on the West Coast. Single tax was given the credit. Single Tax Exposed claimed most citizens in Vancouver were not familiar with the single tax theory. While admitting that buildings were exempted and land values rapidiy increasing, Shields falsely reported there was a dual tax system that taxed the exemptions exempted by the other tax. He said Canadians certainly would not be single taxers, because they believed in contracts and private land. The prosperity was excused as Vancouver being the right city at the right time.

To counteract Shield's comments about Canada, the Courier and U'Ren sent A. M. Hines, a Clackamas county resident, to Canada to collect statements on single tax. These were published in the single Tax Broacher, a monthly pamphlet produced by U'Ren and Eggleston. Some forty statements were recorded. They a11 expressed the same opinions as noted in the examples. Mr. Nicholas, a real estate agent, told Hines he was opposed to single tax, but admitted it worked we11. Walter Hepburn, a Vancouver B. C. alderman, was well satisfied with single tax. It made his business better and allowed him to make improvements. George Kyle, owner of a music store, pointed to Vancouver's better class of housing as evidence of single tax's soundness. H. Lawrence, a Penticton, B. C., fruit grower, was pleased he was not taxed on improvements. In his area, unimproved land increased in value up to two hundred dollars and two hundred fifty dollars per acre. He said, 
"The system of land value taxation is generally favored by the agricultural classes."23

Single taxers were attacked from all sides. They were going to confiscate the land. They were going to destroy land values. They were going to abolish private property and contracts. They had to meet contradictions that said farmers would pay all the taxes, while someone else like Shields claimed farmers would pay less tax with the rest shifted somewhere else. Single taxers had to establish that railroad franchises would be taxed, while railroads said they would not be taxed. The September, 1912, issue of the Single Tax Broacher tried to deal with the railroad right-of-ways.

A detailed explanation of railroad taxation was presented. U'Ren's zeal for factual information created an explanation difficult to follow. The point narrowed to the Southern Pacific Railroad being valued in Clackamas County during 1910 at $\$ 36,053$ per mile. Single taxers, who in addition taxed the franchise, calculated a total valuation of $\$ 39,635$ per mile. The franchise was considered more valuable than the visible property, and since the people granted the franchise, it should give a return to the people's government. In 1910 , single tax would have collected for Clackamas County an additional $\$ 18,859$ from Southern Pacific.

The Southern Pacific was disenchanted with higher taxes and franchise taxation. They sent hired agents to tell farmers the railroad would be taxed on just the raw land values of the right-of-way. The agents said all the railroads in the entire state would be only taxed $\$ 45,590$ under the proposed single tax. In reality, with single tax the state would have received in $1910 \$ 18,856,555$ from all railroads. 
Assessments and Taxation, Single Tax Exposed, the Single Tax Broacher, and many others as The Deadly Parallel are all part of Oregon's political legacy. Few states have had the experience of such a vigorous pamphlet campaign. Few states have had the right combination of men to produce such a campaign. The pamphlets' influence is difficult to assess. The emotional counter reformers played on fears, turned truth around in one hundred eighty degrees, and denounced the single taxers. The single taxers tried to avoid emotion and presented facts with logic to highlight single tax's financial advantages for the average wage earner. If the election results are any guide, emotion and fear were the strongest political weapons. 
FOOTNOTES FOR CHAPTER V

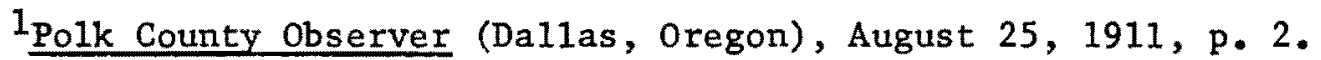

2Edith Forbes, The Freeman: A Magazine of Social Criticism

(Seattle: M. A. Thesis, University of Washington, 1930), p. 72. p. 4 .

${ }^{3}$ Oregon City Courier (Oregon City, Oregon), December 1, 1911 ,

${ }^{4}$ Ibid., August 11, 1911, p. 4.

5Ibid., August 25, 1911, p. 1 .

${ }^{6}$ Ibid., September 15,1911, p. 2.

${ }^{7}$ Ibid., p. 8.

${ }^{8}$ Ibid., October 6, 1911, p. 4.

${ }^{9}$ Ibid., December 29, 1911, p. 1.

10 Ibid.

${ }^{11}$ Ibid., Apri1 26, 1912, p. 2.

12 Ibid., June 7,1912, p. 4.

${ }^{13}$ Ibid.

${ }^{14}$ Ibid., October 27, 1911, p. 1 .

15W. G. Eggleston and W. S. U'Ren, Clackamas County Assessments and Taxes in 1910 (Portland, Oregon: Multnomah Printing Co., 1912), p. v.

160regon, Abstract of Votes, (Secretary of State, December, 1910).

17 Eggleston and U'Ren, Clackamas County Assessments and Taxes in 1910, pp. vi-vii.

$18_{\text {Ibid. }}$ p. xi.

19 Ibid., p. xviii.

20 Ibid. 
21 Charles H. Shields, Single Tax Exposed (Portland, Oregon: Oregon Equal Taxation League, 1912), p. 10.

22 Ibid., pp. 32-3.

23W. S. U'Ren, "Railroad Fra-chise and Right of Way," Single Tax Broacher, September, 1912, Pp. 1-2. 
CHAPTER VI

SURPRISES, ACCUSATIONS, AND DEBATES

\section{A MARCH STATEMENT AND THE MAY PETITION}

The purpose of Section la was to permit tax petitions in the counties. In 1910, U'Ren believed a state-wide single tax measure would fail. The first indication that he might change his mind was noticed during September, 1911. Attomey Genera1 Crawford advised the Secretary of State not to accept single tax petitions from individual counties. A 1907 law was referred to which prohibited such initiative measures, while the Attorney General ignored Section la. U'Ren brought the matter to the Oregon Supreme Court, where he won. In the process, he said if the Supreme Court supported the Attorney General, the single taxers would provide a state-wide measure. If this had to be done, he believed there was a slight chance of its approval.

To counteract the county single tax measures and to give farmers another altemative to the state's serious tax problems, the Assessor of Multnomah County proposed a state-wide graduated tax. The exact details are lacking, but U'Ren's forces were concerned about its Influence. Brief comments in the press indicated some interest. 1 If the Assessor's plan were placed on a petition, single tax would be in trouble. Once again U'Ren considered the practicability of a statewide single tax measure. 
As the 1912 campaign developed, the more perceptive voters believed the tax reforms presented by the State Tax Commission and the special 1911 legislative committee would only create greater confusion while providing a patchwork tax system. Meanwhile, the committee and the Commission charged that county single tax measures would do the same thing. Single taxers were aware of this but were hoping the entire state would quickly adopt single tax once several counties experimented with 1t. However, the pressures for a state-wide single tax initiative were building.

On March 24, 1912, A. D. Cridge, a co-aurhor of single tax publications, declared single taxers would not submit a state-wide measure in November. ${ }^{2}$ Such a decision would not permit the thorough campaign needed in the three counties. It would be to the opposition's advantage if there were a state-wide measure. The single taxers would be spread too thin, and individual attention to voters virtually impossible. At the end of his remarks, Cridge emphasized that only the important counties would sponsor the single tax initiatives. Two months later, U'Ren caught the state unawares. While the exact reasons are uncertain, U'Ren began circulating an initiative petition for a state-wide graduated single tax. He had always demonstrated a keen sense of voter interest and understood practical politics. Some pressure within the single tax ranks, interest in the proposed graduated tax, and pressure to avoid a patchwork tax system all contributed to his decision. The People's Power League believed the state measure complemented the three local county option bills while reducing the state leve1 tax for farmers and wage earners. Farmers were still 
having difficulty accepting the county single tax bills. Thus the graduated measure was specifically designed to show doubtful farmers that railroads and other big businesses would be assessed under single tax.

It can be assumed the state measure was not U'Ren's first preference. U'Ren had the ability to arrange political moves over a long time, and on his schedule, a state initiative in 1912 was premature. However, he realized his influence with voters was weakening, and every alternative needed scrutiny if single tax was to be a reality. Thus, voters in Multnomah, Clackamas, and Coos Counties had two single tax measures to consider, while rest of the state would make a single decision.

True to the U'Ren tradition, the graduated single tax was the most extraordinary measure single taxers submitted in the nation. 3 The initiative provided for exemption of a11 personal property. This part of the bill was law unless the county voted otherwise. Fifteen percent of the voters were needed to put such an initiative on the ballot rather than the usual five percent. While not explained by the single taxers, the -requirement for fifteen percent was to protect the law from the Republican Machine and big business. Critics of the day labeled this provision the most distinctive and radical part of the measure. 4 The graduated feature was similar to the New Zealand land tax. Its design would not break up large land holdings. The wording had farmers in mind:

Providing for graduated taxes upon all franchises, rights of way, lands and other natural resources in excess of $\$ 10,000$ under one ownership and assessing water powers: Exempting al1 personal property and improvenent. 5 
The counties would collect the tax and first pay their share of state revenue. Al1 the surplus revenue was to be used for schools, highways, and genera1 expenditures in that order. This tax, referred to as a special tax for large land holdings and franchises, provided for two dollars and fifty cents to be collected for every $\$ 1,000$ of value between $\$ 10,000$ and $\$ 20,000$. There were nine stages building up to a rate of thirty dollars in taxes per $\$ 1,000$ over $\$ 100,000$ of valuation. Oregon's corporation lawyers labeled the graduated tax as pure "single tax with a few deceptive frills."6 special interests told voters the graduated tax discriminated against holdings concentrated In one area. Since the tax was collected at the county level, they said a speculator holding $\$ 10,000$ or more of land distributed over several counties would not pay any tax, while a large holding concentrated in one county would pay a large $\operatorname{tax} .7$ To this argument, the single taxers reminded their detractors of the county single tax measures under Section 1a. A very clever argument against both the county option bi1ls and the graduated tax dealt with the Public Domain lands. These lands were granted to farmers and speculators with a perpetual contract issued on the basis of improvements being made on the 1and. Counter reformers argued that single tax would destroy land value and consequently the perpetual contract. To the farmer, this would not permit him to will his land to his children. The aspect of leaving land to future generations was important to Oregon farmers.8 
II. THE 1912 ANNUAL STATE GRANGE MEETING

As U'Ren's state graduated single tax initiative got under way, the Grangers met in Roseburg from May 14 to 17 . Outside of government reforms, which have been discussed, their interest was in Oregon's tax crisis. On the afternoon of the third day, Ben Selling, President of U'Ren's 1912 People's Power League, spoke to the issue. He explained his loyalty to the initiative, referendum, and other reforms belonging to the Oregon System. When it came to single tax, he denounced the measure, and made it clear he would not support it. U'Rer was present when Selling spoke, but his reactions are not recorded. He must have suffered disappointment and possible embarrassment because Sel1ing was representing his league.

The Assessment and Taxation Committee read their report with a special sub-committee report on single tax. They were largely uncommitted on the State Tax Commissions's and the 1911 legislative tax proposa1s. Standard Oil was denounced for trying to take private property without compensation. Most of the injustice in taxation was blamed on the county assessors and the county boards of equalization. The State Tax Commission escaped any investigation or condemnation. While the report's influence was devastating, it lacked depth, and failed to answer Oregon's tax problens. It played into the hands of special interests.

Single tax was condemned as an attempt to impair obligations and contracts. The sub-committee believed the single taxers were guilty of duplicity, while their measures contained delusions and snares appealing to all classes. In the report's estimation, single taxers 
were holding out bait to various groups. "The "bait" held out to labor was especially obnoxious to the Grangers. In the ommittee's view, single tax simply could not raise wages, as U'Ren and others maintained. Even the evidence from Vancouver, B. C., was overlooked. It was declared the "great cry of single taxers who shed copious tears over the unearned increment" of the speculator's land was insincere. The influence of special interests was noticeable in charges that single tax would not tax corporation stocks. Grangers denied that a monopoly of land existed, while private property was sound and necessary. Fels was questioned. Grangers feared he was planning to buy all of Oregon's "fertile valleys" after single tax destroyed property values. Again, the Vancouver, B. C., experience was lost on the sub-committee. In the last exasperated sentence, the report declared, "the principal of single tax is fundamentally unjust, unreasonable and inconsistent, its adoption would mean ruin to farmers of oregon." 9

After the taxation reports were delivered, a motion was made to adopt them. Brother $U^{\prime}$ Ren rose and spoke in defense of his single tax measures for twenty minutes. A1though his remarks were not recorded, the Grangers were impressed. After his first twenty minutes were finished, a brother moved that $U^{\prime}$ Ren be allowed to speak another twenty minutes. While the Grangers may have enjoyed $\mathrm{U}^{\prime}$ Ren's speaking ability, they did not appreciate single tax. The vote was taken, and the reports were adopted.

After the Grange taxation reports were made public, Editor Brown exploded. He was appalled by farmers being duped through scare tactics. To say that single tax was communism, and that property would be 
confiscated was ridiculous. Brown contended that oregon was too wealthy for the high taxes farmers were paying. Pointing to the recent history of increasing taxes, the editor told farmers they were going to lose their land anyway, because soon they would not be able to pay any kind of tax, single tax or otherwise. 10

\section{THE SHIELDS AND BROWN LETTERS}

Several months after the annual state Grange meeting, Brown chose to bring Shields, the secretary of the Oregon Anti-Single Tax League into full public view. This move was a shift in the single taxer's tactics. Up to this point, they had mainly spoken to the issue, including certain state agencies. Now, single taxers were concentrating on the leading private detractor of single tax. Shields had remained in the background, only speaking through pamphlets and a corps of lecturers. 11

As a manner of speaking, Brown "exposed" Shields by publishing a series of letters between them. On July 3, Shields wrote to Brown explaining that Governor West had asked the league to withdraw their petition against single tax. The petition already had 15,000 signatures, wrote Shields, but because the league and the State Tax Commission were doing the same work, they should join forces. Governor West asked that both the repeal of Section la and defeat of single tax be their goals. Since, according to Shields, "this league is without a millionaire Joseph Fels to furnish funds for its propaganda," editor Brown should be willing to join the fight against single tax.

Shields offered Brown prepared material from the Oregon AntiSingle Tax League. The material was promised to be "interesting, newsy, 
never prosy, and exclusive." Even the cartoons were guaranteed to be alive and exclusive in the Courier's territory. If Brown would cooperate, Shields promised to buy a number of Courier subscriptions. Al1 Brown had to do was to fill in a post card and return it to the league headquarters.

Brown's reply backed the poor man's opportunities provided by single tax. He was amused by Shield's comment about not having a millionaire's backing as the single taxers had. Brown reminded him that H. L. Pittock, the Oregonian's new owner, and other wealthy speculators were behind the opposition to single tax. The Courier was indignant that some other organization wanted to think for them. Brown was surprised that Shields would even suggest it, since his editorials supported single tax. In closing, Brown expressed concern that anyone in Oregon would deny voters the right to decide if they wanted single tax or not, by repealing Section 1 .

Shortly afterwards, Shields replied, assuring Brown that he was not trying to buy anything from a single tax paper. He said the motive was to promote both sides of the issue. This time, Shields made a direct request for several subscriptions. Brown quickly answered, saying his paper was not for sale. He then described the Courier's policy of printing both sides of the issue with the real concerns of the readers. Brown challenged Shields to send out material in favor of single tax, and asked if the Anti-Single Tax League would publish any of the Courier's material favoring single tax. Shields did not reply to this challenge, and the exchange was over. 12 
U'Ren wrote to Joseph Fels in London, explaining the duel between Shields and Brown. Fels wrote Brown a letter congratulating the editor on his ability to bring Shields out into the open. Fels was very sarcastic towards Shields and his attempt to buy public opinion. 13 Single taxers were delighted with the incident, as it was a rare opportunity to expose in such documented detail the workings of the opposition. It forced Shields to make himself more known to the public, and gave single taxers more opportunity to discredit him. Some farmers disliked Shields, and because of him would have voted for single tax were it not for their fear of it.

slowly, information was discovered about Shields. He came from Seattle, Washington, where he was a grain speculator. There were some connections with a Portland based bank as we11.14 U'Ren charged he was hired by Pittock and the railroads with support from land speculators. The reformers challenged him to reveal the source of his support, which Shields repeatedly refused to do. Evidence did hint that Shields was working for four hundred dollars per month, plus all his expenses. But voters were willing to overlook the source of Shield's support because of the fear he generated over single tax.

\section{U'REN CHALLENGES THE OPPOSITION TO DEBATE}

U'Ren favored both printed material and debating. Pamphlets could easily be printed, but arranging debates with important opponents was difficult. U'Ren viewed speeches as less effective. However, Shields' men preferred speeches to both pamphlets and debates. One commented to Brown, after being asked to contribute his views for the 
Courier, that he did not have to present wiritten arguments. He told Brown, "A two minute scare talk, and one minute funny story will set more farmers against it (single tax) than a dozen newspaper stories." He continued to say that Clackamas County farmers were "boneheads" to be so easily led.15

Because of the opposition's attitudes, U'Ren became frustrated at his inability to arrange debates. In debates, he believed he held the advantage because of his emphasis on truth and detail. Brown shared U'Ren's feelings, and lamented that Oregon's famous orators, who opposed single tax, continually refused to debate with U'Ren. Judge Brownel1, state senator Dimick, and others who were ready to "talk on any subject at the drop of a hat," avoided single tax debate "like a kid from prayer meeting."16 As a debator, U'Ren was powerful, and the opposition did not want to provide him with a public platform. They were fearful he might sway votes and expose the defects and goals of the general tax laws and the special interests.

Some debates and significant speeches did occur during the early and latter phases of the 1912 campaign. On the part of single taxers, the middle months were noticeably absent of such activity. Opponents of single tax were frightened by the early debates and speeches of $U^{\prime}$ Ren and other single taxers because they struck too close to the truth. Anything that threatened the opposition's hold on the farmers, laborers, and small businessmen was avoidel. A series of debates took place during October only because the Grange was becoming suspicious of Shields. 
The first significant debate took place on Friday night, March 8 , in the Beaver Creek Grange ha11, located near Oregon City. On that night, the debators were U'Ren and the mayor of Oregon City, G. B. Dimick. A fairly large audience of two hundred people was present for the occasion. ${ }^{17}$ U'Ren took the position that Dimick had ridiculed the Oregon System since 1898. Dimick did not deny it, but assured the farmers he sympathized with most reform measures. 18

U'Ren charged Dimick of supporting big business interests. While not directly answering U'Ren's accusation, Dimick quoted from U'Ren's People's Power and Public Taxation, printed for the 1910 campaign. Dimick's intent was to show that U'Ren favored confiscation of al1 1and, while the mayor wondered who would pay the difference after taxes were removed from the improvements farmers made. U'Ren clearly demonstrated that speculators and franchise interests would be assessed for the difference. U'Ren a1so quoted from Clackamas County Assessments and Taxation in 1910, which, at the time, was not ready for publication. The quotes revealed U'Ren's desire to lessen the famers' tax load, and to shift more taxes to speculators. Dimick said the figures were arranged to favor farmers, while implying the deputy assessor who helped prepare the document believed the roll was not accurate. Dimick was overlooking the deputy's signed statement attesting to the roll's accuracy.

After the debate, the press discussed the results. There was wide disagreement over who won. Since winners were judged by the amount of applause, the Oregonian credited Dimick with the victory. The Courier said the audience did not take sides, but gave both men generous 
applause. But when U'Ren immediately challenged Dimick to another debate, he refused. Dimick said he wanted to wait until the Clackamas tax rolls were published. They were published, and it was not until October that Dimick finally said he would not debate again. In an open statement, U'Ren said, "The boys told me not to drive you too hard at Beaver Creek last spring lest I should never get another chance at you." 19

On March 20, another debate took place at the Multnomah County Pamona Grange. In this instance, teams of two men each, for and against single tax, spoke. U'Ren and N. G. Heden debated with H. Stark and Eugene Palmer, both from Portland. The single taxers stressed a new prosperity for farmers and small home owners. According to the opposition, single tax would disrupt both business and values. They claimed the national money system faced an upset with single tax, while all property would be confiscated. The exemption of business and manufacturing was criticized. Each element of the county single tax bills was criticized and exaggerated without presenting the ballance between different parts. U'Ren had a difficult time dealing with the emotional factors, and in the next day's Oregonian, he was reported to have only won five votes. 20 Since the Courier was silent on the debate; it is likely that U'Ren and his partner did lose.

In spite of the Pamona Grange experience, U'Ren could not arrange any more debates until october. The single taxers wanted more, because as the campaign wore on, there was a break in the opposition's arguments. Facts and logic were abandoned, and ridicule with silly statements were presented. Shields, in a speech at Oregon City during early October, 
made statements such as, "Show me the color of the single taxers hair that will dispute this," and, "Let him stand up and have his photograph taken."21 As U'Ren increased his pressure for more debates, some Grangers became concemed over the anti-single tax arguments. Thus, with unexpected help from the Pine Grove Grange in Hood River County, U'Ren was jubilant upon securing a series of debates with Shields. During early October, U'Ren and Shields corresponded on the question of debating. U'Ren initiated the dialogue when he invited Shields to "a joint discussion" of tax measures. Shields' secretary replied, saying perhaps he would join U'Ren in a series of debates after October 25. Shields' hesitancy irritated U'Ren, and he wrote, "considering your brag and bluster at Hood River and other places, this looks to me very much like cowardly dodging."22 At the Pine Grove Grange, Shields had said he would debate with anyone about Henry George. U'Ren wrote again, observing that at Pine Grove, Shields avoided any mention of single tax or other related measures to be decided on in November. Shields was challenged a second time to debate both the county exemption bills and the state graduated tax measure. U'Ren said he would accept a negative answer only if Shields would reveal "who pays for your work in Oregon, what salary you are promised, and what is the total expense of your campaign to date?"23 Shields remained silent.

After Shields made his statement in Pine Grove, H. Mason, master of the Pine Grove Grange, promptly wrote both Shields and U'Ren letters Inviting them to debate. U'Ren inmediately accepted, while Shields denied ever receiving such an invitation. ${ }^{24}$ Mason used the local paper, 
the Hood River News, to reply to Shields' denial. He said "if Shields will now come, we won't doubt his sincerity, but otherwise we will weigh his sincerity in the same balance as his statement of facts relative to this proposed debate." This possibility frightened Shields, and he accepted, not by letter to Mason, but through the press. Mason was irritated and commented, "Mr. Shields' answer to me through the press is in keeping with some of the logic to taxation questions. He dodges the question and answers something I never ask."25

Upon Shield's acceptance, he and U'Ren agreed on the itinerary. U'Ren suggested that Ashland, Medford, Grants Pass, Roseburg, Albany, Corvallis, Salem, McMinnville, Oregon City, Hood River, Dallas, and Portland would be a good start. U'Ren wanted the first debate to be on October 21, in the town of Shields' choice. He assured Shields the debates would attract many more people than the anti-single taxer's speeches. After the usual give and take, the schedule was set. On October 23, they would debate in Portland, in Hood River on the 25th, in Oregon City on the 26th, in Salem on the 28th, and in Portland again on the 29 th. 26 When the schedule was announced, Mason took full credit for getting Shields and U'Ren together. He modestly said this was the greatest political triumph of Hood River County.

On October 23, the first debate, the opponents met in Portland's Bungalow Theater with a crowd said to be nine hundred. During this meeting, the crowd was an active participant. A man shouted out, "Mr. Shields, I'd like to know why you, a Seattle man and not a voter in Oregon, should come here to argue against single tax, and who pays you?" Responding in unison, the audience shouted, "Answer that!" 
Evading the question, Shields replied, "Look at my books."27 He continued, saying U'Ren himself had been to the Oregon Anti-Single Tax League's office to do just that. U'Ren announced that on this occasion, he was told the books were not ready. Much to Shield's noticeable embarrassment, the audience broke into ruckus laughter. U'Ren gave a detailed account of how the Fels Fund operated, and said his salary from the Fund was $\$ 3,000$ per year. 28

At the Pine Grove debate in Hood River, U'Ren was the first speaker, and he opened his remarks with a defense of his pamphlet, Clackamas County Assessments and Taxation in 191.0. He read a number of letters and statements from tax payers in British Columbia who favored their single tax. U'Ren argued that single tax was not an experiment, but a thoroughly tested program. While the Fels Fund was 1iberally supporting the campaign, U'Ren reminded his audience that only as local contributions were made, did the Fund issue matching money. Again, U'Ren challenged Shields to reveal his source of support.

Shields was more careful than when he was in Portland. He defended the general property tax laws because they were the result of centuries of tria1, error, and consolidation. The principle of single tax, he declared, had been repudiated all over the world. Shields said single tax was not a result of public demand, but was being forced on them. Without documentation, he said single tax was not successful in British Columbia, while again failing to reveal the source of his incone.

When U'Ren spoke again, he said:

But I will tell you in a word what my object is. I intend to help make such laws in Oregon that no man can get a 
dollar without working for it and no man sha11 produce a dollar of value without getting it. The full application of Henry George's philosophy would not accomplish this end, a1though I believe it would help a great deal. This graduated single tax amendment is drawn with the express purpose of reducing the tax very greatly on men who work for what they get, at the same time increasing the tax on the fellows who get what the other people work for. There are about 25,000 of these monopolies in Oregon and $I$ count that this amendment will make them pay two-thirds of the state and local taxes, which is twice as much as they are now paying. 29

In the press, neither man was given the victory, and the editor of the Hood River News was concermed. He said that if the general tax laws exempted valuable franchises, water power sites and public service corporations, it was a fair question to ask why the entire system had to be abolished to prevent these exemptions. He believed the inequities that U'Ren spoke of could be adjusted within the existing laws. To bring in an entirely new system was "making the remedy worse than the disease."30 The Hood River News editor predicted that such a drastic change as single tax was more than Oregon voters would grant.

On Saturday night, October 26, Oregon City was filled with excitement. There were several dances and many street corner political speeches, all generated by one of the most exciting political campaigns in Oregon. The Opera House was almost filled to capacity by an audience anxious to witness U'Ren duel with Shields. Single Taxers considered this their ultimate in swaying public opinion. As with the last two debates in the series, the remarks of both men at Oregon City closely followed what was said in Hood River.

$U^{\prime}$ Ren informed the audience that many corporations filed two reports with the State Tax Comnission, one to keep rates up, and another to keep taxes down. Because of this, he said that between 1906 and 
1912, taxes for the average voter doubled. Shields was acknowledged as a bright and forceful speaker, but with so much unrest in Oregon over taxes, he had a hard view to defend. The listeners believed that "U'Ren had Shields going from the first round, hanging over the ropes in the second, and down and out at the finish."31 The score cards, which were used throughout the series, were of little use according to the Courfer, because U'Ren won the audience's overwhelming approval. Single taxers put a lot of their hopes in these debates. They provided one of the finest platforms from which to present their views. This was the critical test in their desires to perfect democracy, while providing true and equal opportunity. U'Ren was confident over single tax's chances, and many shared his view. The special interests were concerned with the debates, because Shields received more public exposure than desired. They were afraid single tax might be appealing to over taxed farmers.

\section{THE VOTERS SAY NO}

In November, 1912, Oregon voters sealed the fate of any additional reforms, not only in government, but also in taxation. Surface taxation reforms were made later, but they were not as deep or complete as single taxers had hoped. The basic inequities still remained with those least able to pay supporting government, while permitting big business to become bigger. The election returns revealed indecisions and frustration on the part of the electorate. What they complained the legislature would not do, they could not do. The voters were unwilling to make any kind of bold decision for fundamental tax reform. Tax policies 
were perhaps simply beyond the understanding of the average voter. Thus, once again leaving tax reform to the legislature, the voting precluded any equitable changes.

Voters turned down most of the tax package proposed by the State Tax Commission and the 1911 legislator. The one minor exception that passed was a proposal to exempt all furniture and jewelry. Exemption of debts, revision of inheritance taxes, uniform taxation rates, and the income tax were all turned down. One vital part of the state's program, the repeal of Section la passed. Section la was the core of the single taxer's program, and its repeal made any future campaigns almost impossible. It carried in part, because the repeal measure contained a provision forbidding the legislature to use the emergency clause with regard to taxation and exemptions. U'Ren's state-wide graduated single tax overwhelmingly failed, while the single tax measures for Multnomah, Clackamas, and Coos Counties also failed. Not only did single taxers fail to advance, but they lost ground. With a little rationalization, the single taxers did realize some benefit from their campaign. U!Ren put doubt in the farmers' minds about the honesty of the State Tax Commission and big business. Therefore, voters did not trust their measures either.

Farmers and wage earners were aware of the need for reform, but they did not trust single tax. The famers especially saw themselves in the middle with single tax on one side and corrupt special interests on the other side. The alternatives were not acceptable to them, and no choice was made. Because U'Ren's governmental reforms were associated with single tax, they also failed. It was difficult for voters to consider them for what they were. 
The 1912 election was Oregon's last major opportunity for many years to establish additional legislation designed to make democracy work even better. The suggested reforms would have reorganized basic structures so every citizen and every minority would have had a more equal opportunity to develop and guide themselves and their government. Few states have had the rare chance to work on perfecting the people's rule. It is possible to point out faults in U'Ren's program, but i.t is difficult to prove that his reforms were unworkable. U'Ren wanted the voters to complete his program, but after November, his work remained largely unfinished. The initiative, referendum, recall, direct election of United States Senators, and the presidential preference primary, which Oregonians had already accepted, was just a beginning. The public was unwilling to accept U'Ren's later reform proposals.

During the campaign, U'Ren was often labeled a communist or socialist. These terms were used in the sense of the single tax confiscating all the land and preventing the citizens from direct government. These connotations were alien to U'Ren's philosophy. He believed that each individual had inherited rights to freely develop within a framework respecting others. Each person was a free agent to be encouraged and cultivated. In U'Ren's view, any law or systems that discouraged or tended to break the human spirit was immoral. These attitudes always made U'Ren optimistic and meticulously moral. With these qualities, he continued throughout his long life, to suggest and prod against heavy odds. U'Ren himself was a free human spirit. His purpose was set. When public opinion opposed him, he remained calm because he had at least continued self-development. Until his death he remained free. 
${ }^{1}$ Oregon City Courier (Oregon City, Oregon), March 1, 1912, p. 4. 20regonian (Portland, Oregon), March 26, 1912, p. 9.

${ }^{3}$ A. N. Young, The Single Tax Movement in the United States (Princeton: Princeton University Press, 1916), p. 39.

${ }^{4}$ James H. Gilbert, "Single Tax Movement in Oregon," Political Science Quarterly, XXXI (March, 1916), p. 36.

$5_{\text {George H. Haynes, "People's Rule in Oregon," Political Science }}$ Quarter1y, XXVI (March, 1911), p. 20.

60regonian (Portland, Oregon), July 19, 1912, p. 10.

7 Ibid., July 24,1912, p. 10.

8Gilbert, "Single Tax Movement in Oregon," p. 36.

9 Oregon State Grange, Proceedings of the 39th State Grange at Roseburg, Oregon (Roseburg, Oregon, 1912), p. 148.

${ }^{10}$ Oregon City Courie $\underline{x}$, June 7, 1912, p. 2.

11 Public Letter of Introduction, Charles $\mathrm{H}$. Shields to J. D. Stevens, Oregon Historical Society, Stevens MSS, 1187.

120regon City Courier, July 12, 1912, pp. 1-2.

13Ibid., August 9, 1912, p. 6.

14W. G. Eggleston, A. D. Cridge, and W. S. U'Ren, People's Power and Public Taxation (Portland, Oregon: Multnomah Printing Company, 1910), p. xii.

${ }^{15}$ Oregon City Courier, October 13, 1912, p. 4.

${ }^{16}$ Ibid., October 11, 1912, p. 1.

${ }^{17}$ Oregonian, March 10, 1912, p. 18.

${ }^{18}$ Oregon City Courier, March 15, 1912, p. 1.

${ }^{19}$ Tbid., October 18, 1912, p. 1. 
${ }^{20}$ Oregonian, March 22, 1912, p. 8.

${ }^{21}$ Oregon City Courier, October 11, 1912, p. 1.

${ }^{22}$ Ibid. , October 4, 1912, p. 1 .

${ }^{23}$ Ibid., October 11, 1912, p. 1.

24 Hood River News (Hood River, Oregon), October 16, 1912, p. 4.

25 Ibid., October 23, 1912, p. 1.

${ }^{26}$ Oregon City Courier, October 18, 1912, p. 1.

27 Portland News (Portland, Oregon), October 25, 1912, p. 2.

28 Oregon City Courier, October 18, 1912, p. 1.

${ }^{29}$ Hood River News, October 30,1912, p. 10.

${ }^{30}$ Ibid. , p. 4.

${ }^{31}$ Oregon City Courier, November 1,1912, p. 1. 
SELECTED BIBLIOGRAPHY

I. Primary Sources

A. News Papers

Enterprise (Oregon City, Oregon), 1908-1912.

Evening Telegram (Portland, Oregon), 1910-1912.

Hood River News (Hood River, Oregon), 1911-1912.

Oregon City Courier (Oregon City, Oregon), 1908-1912.

Oregon Daily Journal (Portland, Oregon), 1908, 1910, 1912.

Oregonian (Portland, Oregon), 1908-1912.

Po1k County Observer (Da1las, Oregon), 1910-1912.

Portland News (Portland, Oregon), 1911-1912.

Record Chieftain (Enterprise, Oregon), 1911-1912.

B. Oregon State Documents

Board of State Tax Commissioners. First Biennial Report. Salem, Oregon: State Printer, 1911.

Oregon. Abstract of Votes. Secretary of State, June, 1908.

Oregon. Abstract of Votes. Secretary of State, December, 1910.

1911 Oregon State Legislature. General Laws of Oregon. Salem, Oregon: State Printer, 1913.

Report of the Board of Commissioners. F. W. Mulkey, Chairman. Salem, Oregon: State Printer, 1906.

Reports of the Supreme Court of Oregon. Vo1. 68. F. A. Turner, Reporter. San Francisco: Bancroft Whitney, Co., 1914.

C. Pamphlets

Eggleston, W. G., A. D. Cridge, and W. S. U'Ren. People's Power and Public Taxation. Portland, Oregon: Multnomah Printing Company, 1910. 
Eggleston, W. G. and W. S. U'Ren. Clackamas County Assessments and Taxes in 1910. Portland, Oregon: Multnomah Printing Co., 1912 .

Kaufiman for Land Commissioner Conmittee. Better Times. Washington State: 1908.

Shields, Charles H. Single Tax Exposed. Portland, Oregon: Oregon Equal Taxation League, 1912.

U'Ren, W. S. Introductory Letter, a Bill and Amendments. Oregon City, Oregon: By the Author, Oregon City, 1909.

- Introductory Letter, Draft of Suggested Amendment for Representative Government. Oregon City, Oregon: By the Author, Oregon City, 1911.

- "Railroad Franchise and Right of Way." Single Tax Broacher, September, 1912, pp. 1-3.

D. Persona1 Papers

Bourne Papers. University of Oregon.

Chamberlain MSS, 1025. Oregon Historical Society.

Stevens MSS, 1187. Oregon Historical Society.

E. Published Private Documents

Oregon State Grange. Proceedings of the 37 th Annual Session of the Oregon State Grange. Oregon City, Oregon, 1910.

Oregon State Grange. Proceedings of the 39th State Grange at Roseburg, Oregon. Roseburg, Oregon, 1912.

II. Secondary Sources

A. Books

Baker, Ray Stannard. Woodrow Wilson: Life and Letters, 1910-13. Garden City, New York: Doubleday, Co., 1927.

Brown, H. G. Land Value Taxation Around the World. New York: Robert Schalhenback Foundation, 1955.

George, Henry. Progress and Poverty. New York: Doubleday, 1899. 
Haynes, George H. The Senate of the United States. Vol. 1. Boston: Houghton Mifflin Co., 1938.

Young, A. N. The Single Tax Movement in the United States. Princeton: Princeton University Press, 1916.

\section{B. Journal Articles}

Croly, Herbert. "State and Political Reorganization." Supplement to the American Political Science Review, VI (February 1912), 121-30.

Gilbert, James H. "Single Tax Movement in Oregon." Political Science Quarterly, XXXI, (March 1916), 29-36.

Haynes, George H. "People's Rule in Oregon." Political Science Quarterly, XXVI (March 1911), 28-37.

"People's Rule on Trial." Political Science Quarter1y,
XXVIII (March 1913), 17-24.

U'Ren, W. S. "State and County Government in Oregon and Proposed Changes." Annuals of the American Academy of Political and Social Sciences, XXXXVII (May 1913), 264-74.

- "Single Tax." Readjustments in Taxation, LVIII (March 1915), 221-26.

Woodward, Robert C. "W. S. U'Ren." Idaho Yesterdays, LV (Sumer 1960), 44-49.

Young, F. G. "Public Finance." American Economic Review, I (November 1911), 640-49.

C. Magazine Articles

Hendrick, Burton J. "Statement No. 1." McClure's Magazine, September 1911, pp. 502-13.

Oregon Agriculturist. Editorial, November 1, 1912.

Stockbridge, Frank Parker. "The Single Taxers." Everybody's Magazine, April 1912, pp. 505-25.

D. Theses and Dissertations

Forbes, Edith. The Freeman: A Magazine of Social Criticism (Seatt1e: M.A. Thesis, University of Washington, 1930). 
Reed, Scott W. W. S. U'Ren and the Oregon System. Princeton: A.B. Thesis, Princeton University, 1.950.

Weinstein, Esther G. William Simon U'Ren: A Study of Persistence in Political Reform. Syracuse: Ph.D. Dissertation, Syracuse University, 1967.

Woodward, Robert C. William Simon U'Ren: In an Age of Protest. Eugene: M.A. Thesis, University of Oregon, 1956. 